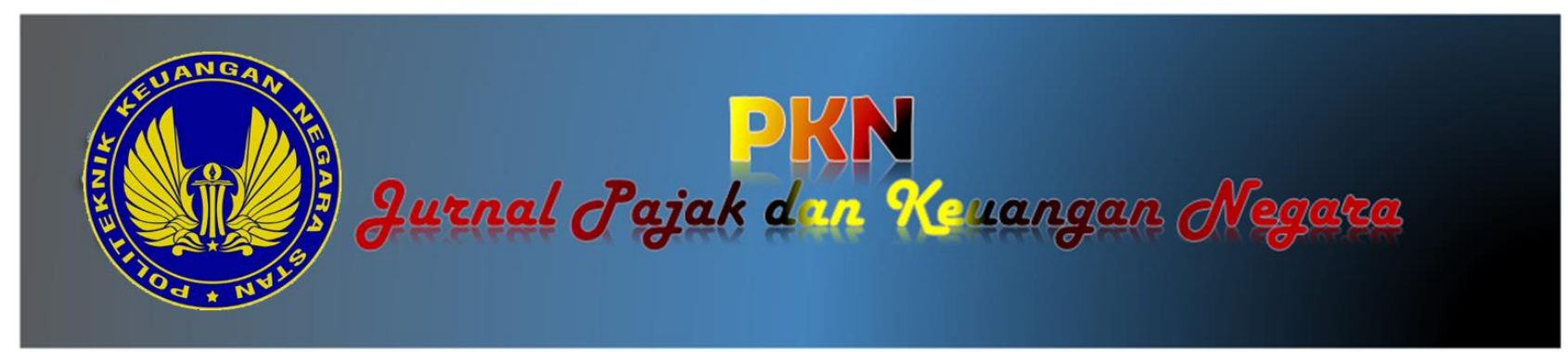

\title{
PENGARUH PEMERIKSAAN PAJAK TERHADAP KEPATUHAN WAJIB PAJAK BADAN DI INDONESIA
}

\author{
Arif Nugrahanto, \\ Politeknik Keuangan Negara STAN \\ Soupani Andri Nasution, \\ Direktorat Jenderal Pajak, Kementerian Keuangan RI
}

Alamat Korespondensi: [arifn@pknstan.ac.id]

\section{INFORMASI ARTIKEL}

Diterima Pertama

[27 September 2019]

Dinyatakan Diterima

[31 Oktober 2019]

\section{KATA KUNCI:}

Pemeriksaan; Kepatuhan; Wajib Pajak Badan; difference-in-differences.

\section{ABSTRACT}

Several studies related to the effect of audits on taxpayer compliance provide different conclusions. Bergman and Nevarez (2006) find the fact that tax audits negatively affect compliance. In contrast, Gemmel and Ratto (2012) concluded that the audit had a negative effect on the group of taxpayers who obeyed, and at the same time had a positive effect on the group of taxpayers who did not comply. Given the different conclusions, the researcher is interested in testing in the Indonesian context by using the SIDJP data from the Directorate General of Tax for the period 2009-2013.

The difference-in-differences approach model implemented in this study adopts Norman Gemmell and Marissa Ratto (2012). The dependent variable is income tax while the independent variable is the dummy variable for group, time and type of audits. Regression results show that the interaction coefficient between the dummy group variable and the time dummy variable which is the difference-in-differences coefficient, has a p-value that is statistically insignificant to reject null hypothesis. It tells that there is no difference in the level of compliance between the audited (corporate) taxpayer and non-audited (corporate) taxpayers. No impact on the level of compliance of taxpayers may come from several reasons, including the small coverage of the tax audits, the existence of the bomb crater effect, and the results of the type of updating audit risk.

\section{ABSTRAK}

Beberapa penelitian yang terkait pengaruh pemeriksaan terhadap kepatuhan Wajib Pajak memberikan simpulan yang berbeda-beda. Bergman dan Nevarez (2006) mendapatkan fakta bahwa pemeriksaan pajak berpengaruh negatif terhadap kepatuhan. Gemmel dan Ratto (2012) menyimpulkan bahwa pemeriksaan berpengaruh negatif terhadap kelompok Wajib Pajak patuh, dan pada saat yang sama berpengaruh positif untuk kelompok Wajib Pajak tidak patuh. Dengan adanya perbedaan kesimpulan yang dihasilkan tersebut, Peneliti tertarik untuk menguji dalam konteks Indonesia dengan menggunakan data Wajib Pajak Badan yang terdaftar dalam Sistem Informasi Direktorat Jenderal Pajak dalam jangka waktu tahun 2009-2013.

Model pendekatan difference-in-differences yang digunakan dalam penelitian ini mengacu pada penelitian Norman Gemmell dan Marissa Ratto (2012). Variabel dependen yang digunakan adalah yaitu Pajak Penghasilan (PPh) sedangkan variabel independen adalah variabel dummy. Hasil regresi menunjukkan bahwa koefisien interaksi antara variabel dummy grup dengan variabel dummy waktu yang merupakan koefisien difference-in-differences, memiliki $p$-value yang secara statistic tidak signifikan untuk menolak HO yang menyatakan tidak terdapat perbedaan tingkat kepatuhan antara Wajib Pajak Badan yang diperiksa maupun Wajib Pajak yang tidak mengalami pemeriksaan pajak. Tidak adanya perbedaan tingkat kepatuhan Wajib Pajak antara lain disebabkan oleh beberapa hal, antara lain kecilnya cakupan pemeriksaan pajak (Audit Coverage Ratio), adanya fenomena bomb crater effect dan hasil typeupdating risiko pemeriksaan. 


\section{PENDAHULUAN}

Pajak memiliki peran yang vital dalam perekonomian suatu negara tak terkecuali di Indonesia, hal ini dapat dilihat dari persentase penerimaan negara dalam postur APBN dari tahun ke tahun. Pajak digunakan tidak hanya sebagai instrumen pendanaan untuk merealisasikan tujuan tersebut tetapi juga sebagai instrumen fiskal yang efektif dan efisien dalam mengarahkan kebijakan perekonomian. Perekonomian juga harus diberi insentif agar tetap berkembang namun para pelaku usaha juga harus membayar pajak agar tujuan kesejahteraan sosial bagi seluruh rakyat Indonesia dapat tercapai.

Kontribusi pajak terhadap APBN sangat signifikan. Berdasarkan APBN, sejak tahun 2000, kontribusi Penerimaan Pajak terhadap seluruh Penerimaan Negara mencapai lebih dari angka 60\%. Namun, sayangnya, dalam beberapa tahun terakhir, Pemerintah selalu gagal mencapai target penerimaan pajak. Menteri Keuangan, Sri Mulyani mengungkapkan bahwa penyebab utama dari tidak tercapainya target penerimaan pajak adalah rendahnya kepatuhan Wajib Pajak dalam memenuhi kewajiban perpajakannya. Untuk menentukan tinggi-rendahnya kepatuhan Wajib Pajak dalam rezim self-assessment system, Pemeriksaan Pajak menjadi suatu keniscayaan.

Dalam sistem dimana Wajib Pajak diberikan kepercayaan yang penuh untuk menghitung, memperhitungkan, menyetor dan melaporkan pajaknya, Pemeriksaan Pajak menjadi instrumen yang penting untuk menentukan benar-salahnya pemenuhan kewajiban perpajakan atau patuhtidaknya seorang Wajib Pajak dalam menunaikan salah satu kewajibannya sebagai seorang Warga Negara. Oleh karena itu, mengetahui pengaruh pemeriksaan pajak terhadap kepatuhan Wajib Pajak menjadi hal yang penting, khususnya dalam penyiapan strategi untuk mengoptimalkan penerimaan negara dari sektor pajak.

Beberapa penelitian yang terkait pengaruh pemeriksaan terhadap kepatuhan Wajib Pajak memberikan simpulan yang berbeda-beda. Bergman dan Nevarez (2006) mendapatkan fakta bahwa pemeriksaan pajak terhadap kepatuhan Wajib Pajak atas value added tax (VAT) di Argentina dan Chile berpengaruh negatif terhadap kepatuhan. Setelah dilakukan pemeriksaan, kepatuhan Wajib Pajak di Argentina dan Chile justru mengalami turun.

Lain halnya dengan Niu (2010). Niu meneliti pengaruh pemeriksaan pajak terhadap kepatuhan Wajib Pajak Badan atas Pajak Penjualan (Sales Tax) di negara bagian New York, Amerika Serikat dan menyimpulkan bahwa pemeriksaan pajak berpengaruh positif. Wajib Pajak semakin patuh setelah dilakukan pemeriksaan.

Peneliti lainnya mendapatkan hasil yang lebih bervariasi. Gemmel dan Ratto (2012) menyimpulkan bahwa pemeriksaan pajak berpengaruh negatif terhadap kelompok Wajib Pajak patuh, dan pada saat yang sama berpengaruh positif untuk kelompok Wajib Pajak tidak patuh. Gemmel dan Ratto melakukan penelitian pengaruh pemeriksaan pajak terhadap kepatuhan Wajib Pajak Orang Pribadi atas Pajak Penghasilan di Inggris.

Dengan adanya perbedaan kesimpulan yang dihasilkan dalam beberapa penelitian mengenai pengaruh pemeriksaan pajak terhadap kepatuhan Wajib Pajak, Peneliti tertarik untuk menguji permasalahan tersebut dalam konteks Pajak Penghasilan di Indonesia dengan menggunakan objek studi Wajib Pajak Badan, yang merupakan sumber penerimaan pajak terbesar di Indonesia.

\section{KERANGKA TEORI DAN PENGEMBANGAN HIPOTESIS}

\subsection{Literature Review}

Centre for Tax Policy and Administration Organisation For Economic Co-Operation And Development (OECD) mendefinisikan pajak sebagai " $a$ compulsory unrequited payment to the government", pembayaran wajib yang tidak mendapatkan imbalan secara langsung kepada pemerintah. Adapun Oxford Dictionaries mendefinisikan pajak sebagai "a compulsory contribution to state revenue, levied by the government on workers' income and business profits, or added to the cost of some goods, services, and transactions" atau dapat diterjemahkan sebagai kontribusi wajib kepada penerimaan negara yang dipungut oleh pemerintah dari penghasilan pekerja dan keuntungan bisnis atau yang ditambahkan kepada harga barang, jasa, dan transaksi. Dalam pengertian lainnya, berdasarkan Concise Encyclopedia Merriam-Webster Dictionary, pajak diartikan sebagai "a general obligation of taxpayers and are not paid in exchange for any specific benefit." atau dapat diterjemahkan sebagai kewajiban umum dari Wajib Pajak yang dibayarkan tanpa mendapatkan imbalan yang khusus.

Prof. Dr. Rochmat Soemitro, SH dalam Mardiasmo (2013: 1) mendefinisikan pajak sebagai iuran rakyat kepada kas negara berdasarkan undang-undang (yang dapat dipaksakan) dengan tiada mendapat jasa timbal (kontraprestasi) yang langsung dapat ditunjukkan dan yang digunakan untuk membayar pengeluaran umum.

Di lain pihak, Prof. Dr. P.J.A. Adriani dalam Sumarsan (2013: 3) mendefinisikan pajak sebagai iuran masyarakat kepada negara (yang dapat dipaksakan) yang terutang oleh yang wajib membayarnya menurut peraturan-peraturan umum (undang-undang) dengan tidak mendapat prestasi kembali yang langsung dapat ditunjukkan dan yang gunanya adalah untuk membiayai pengeluaran-pengeluaran umum berhubung tugas negara untuk menyelenggarakan pemerintahan.

Dari beberapa definisi di atas, dapat disimpulkan bahwa karakteristik pajak adalah sebagai berikut, yaitu merupakan iuran wajib yang dipungut oleh negara; berdasarkan undang-undang (yang dapat dipaksakan); tidak mendapatkan imbal balik secara langsung; dan digunakan untuk membiayai pengeluaran umum. 
Sistem pemungutan pajak adalah suatu cara bagaimana pajak dapat dipungut dan menentukan siapa yang menghitung pajak. Sumarsan (2013: 14) membagi sistem pemungutan pajak menjadi tiga kategori yaitu: Official assessment system, Selfassessment system, dan Withholding system. Di antara ketiga system tersebut, sejak 1983 Indonesia mengadopsi Self-assessment system, yaitu suatu sistem pemungutan pajak yang memberi wewenang, kepercayaan, dan tanggung jawab kepada Wajib Pajak untuk menghitung, memperkirakan, membayar, dan melaporkan sendiri besarnya pajak yang harus dibayar.

Centre for Tax Policy and Administration Organisation For Economic Co-Operation And Development (OECD) mendefinisikan self-assessment system sebagai

"System under which the taxpayer is required to declare the basis of his assessment (e.g. taxable income), to submit a calculation of the tax due and, usually, to accompany his calculation with payment of the amount he regards as due. The role of tax authorities is to check (perhaps in random cases) that the taxpayer has correctly disclosed his income."

Pengertian tersebut dapat diterjemahkan sebagai sistem dimana Wajib Pajak diminta untuk memberitahukan dasar perhitungannya (pendapatan kena pajak), menyampaikan perhitungan dari pajak yang terhutang dan biasanya perhitungan tersebut diikuti dengan pembayaran jumlah pajak yang belum dibayarkannya. Peran dari otoritas perpajakan adalah untuk mengecek apakah Wajib Pajak telah memberitahukan pendapatannya dengan benar.

Andrew Okello (2014) menguraikan beberapa karakteristik dari sistem self-assessment antara lain:

1. Sistem self-assessment digunakan karena pada realitasnya tidak ada otoritas perpajakan yang memiliki atau akan pernah memiliki sumber daya yang cukup untuk menentukan jumlah kewajiban yang benar dari setiap Wajib Pajak.

2. Self-assessment berdasarkan pada ide kepatuhan sukarela.

3. Sistem self-assessment tidak membutuhkan banyak informasi dan dokumen pendukung ketika proses penyampaian Surat Pemberitahuan (SPT).

4. Peran otoritas perpajakan dalam self-assessment yang pertama dan paling utama adalah membantu Wajib Pajak untuk memahami hak dan kewajibannya berdasarkan Undang-Undang.

5. Dalam sistem self-assessment, otoritas perpajakan lebih mengandalkan kontrol setelah penyampaian SPT seperti pemeriksaan berdasarkan resiko, penagihan, dan penyidikan terhadap pengemplang pajak.

Selain itu, Okello (2014) menguraikan beberapa kondisi yang diperlukan untuk keberhasilan sebuah sistem Self-Assessment antara lain:

1. Peraturan perundang-undangan perpajakan yang jelas dan sederhana.

2. Adanya pemberian pelayanan yang baik kepada Wajib Pajak.
3. Prosedur pelaporan dan pembayaran pajak yang sederhana.

4. Terdapat proses penegakan hukum dan penagihan pajak yang efektif.

5. Terdapat Pemeriksaan pajak berdasarkan analisis risiko yang selektif.

6. Sanksi dan bunga diterapkan secara adil.

7. Terdapat penanganan Keberatan Pajak yang adil dan tepat waktu.

Salah satu kondisi yang diperlukan agar sistem Self-Assessment dapat berjalan dengan efektif, adalah terdapat pemeriksaan pajak berdasarkan analisis risiko yang selektif. Dalam information note yang diterbitkan pada tahun 2006 dan berjudul "Strengthening Tax Audit Capabilities: General Principles and Approaches", OECD mendefinisikan pemeriksaan pajak sebagai "an examination of whether a taxpayer has correctly assessed and reported their tax liability and fulfilled other obligations.". Dari pengertian tersebut, pemeriksaan pajak dapat diartikan sebagai sebuah proses untuk memastikan apakah Wajib Pajak telah menghitung dan melaporkan kewajibannya serta telah memenuhi kewajiban-kewajiban lainnya dengan benar.

Selanjutnya dalam information note tersebut OECD menyebutkan beberapa peran penting dari pemeriksaan pajak antara lain sebagai berikut:

1. Meningkatkan kepatuhan sukarela Wajib Pajak.

2. Mendeteksi ketidakpatuhan dalam tingkatan Wajib Pajak Individual.

3. Memperoleh informasi mengenai "kesehatan" dari sistem perpajakan (termasuk pola-pola perilaku kepatuhan Wajib Pajak).

4. Memperoleh pengetahuan dan informasi.

5. Sarana edukasi Wajib Pajak.

6. Mengidentifikasi area dalam undang-undang perpajakan yang memerlukan klarifikasi atau penegasan.

Pemeriksaan pajak merupakan karakteristik utama dari mekanisme kepatuhan sukarela dalam sistem self-assessment karena dengan semakin tinggi tingkat pemeriksaan akan dapat meningkatkan kepatuhan pajak (Allingham dan Sandmo dalam Isa dan Pope, 2010). Dalam konteks perpajakan di Indonesia, pengertian pemeriksaan pajak yang diatur dalam Undang-Undang Ketentuan Umum dan Tatacara Perpajakan Nomor 28 Tahun 2007 (selanjutnya disebut UU KUP) sebagaimana tercantum dalam Pasal 1 angka 25 adalah

"serangkaian kegiatan menghimpun dan mengolah data, keterangan, dan/atau bukti yang dilaksanakan secara objektif dan profesional berdasarkan suatu standar pemeriksaan untuk menguji kepatuhan pemenuhan kewajiban perpajakan dan/atau untuk tujuan lain dalam rangka melaksanakan ketentuan peraturan perundang-undangan perpajakan". 
Adapun tujuan dilakukannya pemeriksaan adalah salah satunya adalah menguji kepatuhan pemenuhan kewajiban perpajakan.

Centre for Tax Policy and Administration Organisation For Economic Co-Operation And Development (OECD) mendefinisikan kepatuhan sebagai "Degree to which a taxpayer complies (or fails to comply) with the tax rules of his country, for example by declaring income, filing a return, and paying the tax due in a timely manner.". Pengertian ini dapat diterjemahkan sebagai suatu ukuran dimana Wajib Pajak mematuhi atau tidak dapat mematuhi peraturan perpajakan di negaranya, sebagai contoh dengan memberitahukan penghasilan, menyampaikan SPT, dan membayar pajak yang terhutang tepat pada waktunya.

Internal Revenue Service (IRS), otoritas perpajakan Amerika Serikat, membagi kepatuhan menjadi 3 jenis yaitu filing compliance, report compliance, dan payment compliance. Filing compliance adalah kepatuhan dalam menyampaikan surat pemberitahuan (SPT), report compliance adalah kepatuhan dalam menyampaikan jumlah penghasilan yang didapatkan dengan benar, dan payment compliance adalah kepatuhan dalam melakukan pembayaran pajak yang masih terutang secara tepat waktu (Brown dan Mazur, 2003).

Nurmantu (2005) menyatakan bahwa kepatuhan Wajib Pajak dapat didefinisikan sebagai suatu keadaan dimana Wajib Pajak memenuhi semua kewajiban perpajakan dan melaksanakan hak perpajakannya. Nurmantu kemudian membedakan kepatuhan tersebut menjadi dua yaitu kepatuhan formal dan kepatuhan material. Kepatuhan formal adalah suatu keadaan dimana Wajib Pajak memenuhi kewajiban perpajakan secara formal sesuai dengan ketentuan dalam Undang-Undang Perpajakan. Di sisi lain, kepatuhan material adalah suatu keadaan dimana Wajib Pajak secara substanstif memenuhi serangkaian ketentuan material perpajakan sesuai dengan isi dan jiwa Undang-Undang Perpajakan.

Alm (2012) mengungkapkan bahwa dalam upaya untuk menjelaskan mengenai kepatuhan atau ketidakpatuhan Wajib Pajak, terdapat tiga macam cara, model, atau pendekatan penelitian yang dapat dilakukan. Ketiga pendekatan itu dapat dibedakan menjadi pendekatan teoritis, pendekatan eksperimental, dan pendekatan empiris.

Dalam pendekatan teoritis, penelitian yang dapat dianggap sebagai pelopor dalam bidang Kepatuhan Wajib Pajak adalah Allingham dan Sandmo (1972) dalam penelitian berjudul "Income Tax Evasion: A Theoritical Analysis". Dalam penelitian tersebut, Allingham dan Sandmo menggunakan kerangka teori ekonomi klasik dan teori kegunaan optimum yang dikembangkan oleh Gary Becker dalam penelitian berjudul "Crime and Punishment: An Economic Approach" dan kemudian memposisikan Wajib Pajak sebagai individu yang rasional yang akan menggunakan optimalisasi kegunaan untuk menentukan pilihan kepatuhan perpajakannya. Dalam penelitian tersebut diungkapkan bahwa kepatuhan Wajib Pajak akan tergantung pada tiga variabel yaitu tingkat kemungkinan menghadapi pemeriksaan (audit rate), persentase pajak yang dikenakan atas Wajib Pajak tersebut (tax rate), dan tingkat sanksi yang akan diberikan kepada Wajib Pajak atas pelanggaran/penggelapan pajak yang dilakukan (penalty rate).

Setelah adanya penelitian Allingham dan Sandmo (1972), penelitian tentang kepatuhan Wajib Pajak dengan pendekatan teoritis terus mengalami perkembangan antara lain dengan adanya koreksi terhadap model Allingham dan Sandmo (1972) seperti yang dilakukan oleh Yitzhaki dalam Slemrod dan Yitzhaki (2002) dengan memberikan koreksi bahwa persentase pajak (tax rate) tidak memiliki pengaruh terhadap pilihan kepatuhan Wajib Pajak. Perkembangan lainnya seperti yang dilakukan oleh Andreoni, Errard, dan Feinstein (1998) dengan mencoba memasukkan interaksi antara Wajib Pajak dan otoritas perpajakan seperti adanya keterbatasan sumber daya maupun anggaran dalam pelaksanaan pemeriksaan pajak atau dapat pula dilakukan dengan menggabungkan model yang dikembangkan Allingham dan Sandmo (1972) dengan kerangka teori lainnya seperti yang dilakukan oleh Reinganum dan Wilde (1985) dengan pendekatan Principal-Agent Framework, Erard dan Feinstein (1994) dan Lipatov (2003) dengan pendekatan Game Theory atau Bernasconi (1998) dengan pendekatan urutan penghindaran risiko.

Selain itu beberapa perkembangan lain dari pendekatan teoritis antara lain dengan memasukkan unsur penghindaran pajak (tax avoidance) seperti yang dilakukan oleh Stiglitz (1985). Perkembangan kerangka teori Allingham dan Sandmo (1972) juga dilakukan dengan mengubah teori kegunaan optimum dengan teori prospek yang dipopulerkan oleh Kahnemann dan Tverzky seperti yang dilakukan oleh Gideon (1999), dimana kemudian perbandingan atas kedua teori tersebut diteliti oleh Dhami dan Al-Nowaihi (2004). Selain perkembangan model, pendekatan teoritis juga dikembangkan untuk meneliti dampak tidak langsung kepatuhan Wajib Pajak (Ratto, Thomas, dan Ulph, 2009) dan juga dikembangkan tidak hanya dalam kerangka teori ekonomi tetapi juga dapat menggunakan kerangka ilmu lainnya seperti psikologi seperti yang dilakukan oleh Kirchler, Hoezl, dan Wahl (2008) dengan menggunakan kerangka "Slippery Slope".

Pendekatan teoritis ini pun senantiasa mengalami perkembangan dan tetap dikaji ulang seperti yang dilakukan oleh Sandmo (2005) sendiri dengan mencoba memberikan pandangan retrospektif terhadap kepatuhan Wajib Pajak. Perkembangan lain dilakukan Gahramanov (2009) yang mengkaji ulang perbaikan yang dilakukan oleh Yitzhaki terhadap model Allingham-Sandmo (1972) dan Rablen (2012) yang menawarkan perbaikan atas model Allingham-Sandmo (1972) dengan mengganti variabel tingkat kemungkinan menghadapi pemeriksaan (audit rate) dengan tingkat efektivitas pemeriksaan yang dilakukan. 
Pendekatan kedua yang dapat dilakukan dalam meneliti kepatuhan Wajib Pajak adalah dengan pendekatan eksperimental. Pendekatan eksperimental digunakan untuk menguji teori yang dikemukakan dalam pendekatan teoritis yang kemudian dapat menjadi "bridging" antara dunia teori dengan dunia nyata (Guala dan Mittone, 2005). Pendekatan eksperimental lebih sering digunakan daripada pendekatan empiris karena secara fundamental lebih sulit untuk mendapatkan informasi yang detail dan dapat dihandalkan dari pilihan-pilihan Kepatuhan Wajib Pajak (Alm, Jackson, dan McKee, 1992b). Selain itu pendekatan eksperimental juga lebih diminati karena dengan menggunakan pendekatan tersebut, peneliti lebih dimudahkan untuk dapat mengontrol variabel-variabel yang ingin diuji dengan tetap menjaga agar variabel-variabel lainnya berada dalam kondisi "ceteris paribus" (Alm, 2012; Guala dan Mittone, 2005). Tidak hanya itu, dengan menggunakan pendekatan eksperimental peneliti juga dapat menemukan fenomena perilaku Wajib Pajak yang kemudian dapat memperkaya pendekatan teoritis (Guala dan Mittone, 2005).

Pendekatan eksperimental laboratorium dapat digunakan untuk menemukan dan meneliti fenomena baru yang didapat dari pola perilaku yang ditunjukkan oleh peserta eksperimen yang kemudian dapat memperkaya dunia teori tentang Kepatuhan Wajib Pajak seperti yang dilakukan oleh Guala dan Mittone (2005) dan Mittone (2006) yang menemukan fenomena "bomb-crater effects", "echo effects", dan "gambler's fallacy" dalam perilaku peserta eksperimen tentang Pemeriksaan pajak yang kemudian diteliti lebih lanjut oleh Maciejovsky, Kirchler, dan Schwarzenberger (2007) dan Kastlunger et al. (2009). Tidak hanya itu, penelitian eksperimental laboratorium juga dapat digunakan dalam meneliti efek informasi dan rekan sejawat (Alm, Bloomquist, dan McKee, 2013) ataupun jaringan sosial (Hashimzade et al., 2012) terhadap kepatuhan Wajib Pajak ataupun untuk menguji inisiatif-inisiatif terbaru dalam kebijakan perpajakan seperti pelayanan informasi (McKee, Siladke, dan Vossler, 2011) dan hal-hal lainnya.

Beberapa contoh penelitian eksperimental lapangan antara lain adalah penelitian Slemrod, Christian, dan Blumenthal (2001) yang meneliti tentang respon Wajib Pajak di negara bagian Minnesota terkait dengan surat pemberitahuan akan "lebih diawasinya" Laporan Pajak yang akan disampaikan Wajib Pajak yang terlaksana dengan bantuan Department of Revenue State of Minnesota, Amerika Serikat. Penelitian eksperimental lapangan lainnya yang cukup dikenal adalah penelitian Kleven et al., (2011) yang meneliti tentang respon Wajib Pajak di Denmark terhadap surat "ancaman audit" yang terlaksana dengan bantuan The Danish Tax Administration (SKAT) dan penelitian Pomeranz (2011) yang meneliti tentang penyebaran informasi ancaman pemeriksaan dan proses pemeriksaan dari Wajib Pajak Badan di Chile kepada supplier dalam konteks Pajak Pertambahan Nilai yang terlaksana dengan bantuan The Chilean Tax Authority.
Pendekatan terakhir yang tidak kalah penting dalam mempelajari kepatuhan Wajib Pajak adalah pendekatan empiris. Penelitian tentang kepatuhan Wajib Pajak menggunakan pendekatan empiris pertama kali dimulai oleh Charles T. Clotfelter pada tahun 1983 dan terus berkembang hingga saat ini (Alm, Jackson, dan McKee, 1992b; Andreoni, Errard, dan Feinstein, 1998). Jenis data empiris yang digunakan dapat berupa survey langsung kepada Wajib Pajak maupun data lain yang disediakan oleh otoritas perpajakan seperti total pajak yang dilaporkan oleh Wajib Pajak maupun data-data lainnya yang diperoleh otoritas perpajakan. Kesulitan yang paling utama dalam penggunaan data empiris adalah tidak terdapatnya informasi yang dapat diandalkan untuk menunjukkan perilaku pelaporan pajak dari suatu Wajib Pajak dan informasi empiris dari otoritas perpajakan juga sangat sulit untuk diperoleh pada beberapa negara sehingga banyak peneliti lebih cenderung untuk menggunakan pendekatan eksperimental, meskipun banyak kesulitan yang dihadapi dalam penelitian pendekatan empiris, tidak lantas menghentikan para peneliti untuk melakukan pendekatan empiris (Alm, 2012).

Penelitian empiris dengan menggunakan data yang langsung disediakan oleh otoritas perpajakan terkadang dapat dibagi menjadi dua kelompok besar berdasarkan jenis data yang disediakan yaitu data aggregat dan data individual. Andreoni, Errard, dan Feinstein (1998) menyatakan bahwa untuk penggunaan data aggregat model ekonometri yang digunakan kebanyakan menggunakan model regresi linear sedangkan apabila menggunakan data individual model ekonometri yang digunakan adalah model analisis tobit.

Beberapa contoh penelitian empiris dengan menggunakan data aggregat antara lain adalah penelitian Dubin, Graetz, dan Wilde (1987), Dubin, Graetz, dan Wilde (1990), dan Dubin dan Wilde (1988) yang menggunakan data aggregat Tax Compliance Measurement Programme (TCMP) yang dirilis oleh Internal Revenue Service (IRS), otoritas perpajakan Amerika Serikat untuk meneliti hubungan antara tingkat Pemeriksaan pajak terhadap kepatuhan Wajib Pajak. Alan Plumley (1996, 2002) juga menggunakan data agregat TCMP untuk menguji hubungan antara kebijakan-kebijakan yang dilakukan IRS terhadap Kepatuhan Wajib Pajak di Amerika Serikat. Pendekatan empiris dengan data agregat TCMP juga digunakan oleh Dubin (2004) untuk menguji hubungan investigasi tindak pidana perpajakan terhadap kepatuhan Wajib Pajak di Amerika Serikat dan oleh Birskyte (2013) untuk menguji spillover effects dari pemeriksaan di tingkat federal terhadap kepatuhan Wajib Pajak dalam tingkat negara bagian. Selain menggunakan data TCMP, penggunaan data aggregat juga dapat dilakukan dengan melakukan aggregat dari data individual Wajib Pajak seperti yang dilakukan oleh Niu (2010) dalam menguji hubungan pemeriksaan pajak terhadap kepatuhan Wajib Pajak dalam konteks Sales Taxes negara bagian New York, Amerika Serikat. 
Beberapa contoh penelitian empiris yang menggunakan data individual antara lain adalah penelitian yang dilakukan oleh Witte, Tauchen, dan Beron (1989) yang menggunakan data TCMP secara individual untuk mencari nilai efek tidak langsung Pemeriksaan pajak terhadap kepatuhan Wajib Pajak, penelitian Feldman dan Slemrod (2005) yang mengukur tingkat kepatuhan Wajib Pajak yang tidak diperiksa, dan penelitian Hanlon, Mills, dan Slemrod (2005) yang meneliti hubungan antara ukuran, sektor usaha, dan beberapa karakteristik khusus Wajib Pajak dengan kepatuhan Wajib Pajak tersebut.

Dari penelitian Hanlon, Mills, dan Slemrod (2005) dihasilkan beberapa kesimpulan sebagai berikut:

1. Wajib Pajak dengan ukuran kecil dan besar memiliki tingkat ketidakpatuhan yang lebih tinggi dibandingkan Wajib Pajak ukuran menengah.

2. Wajib Pajak dengan karakteristik sektor usaha tertentu memiliki tingkat ketidakpatuhan yang lebih tinggi relatif jika dibandingkan dengan sektor usaha lainnya.

3. Wajib Pajak dengan usaha multinasional memiliki tingkat ketidakpatuhan yang lebih tinggi dari Wajib Pajak dengan skala usaha nasional.

4. Wajib Pajak privat (yang tidak mendaftarkan diri dalam pasar modal) memiliki tingkat ketidakpatuhan yang lebih tinggi dari Wajib Pajak publik (yang mendaftarkan diri dalam pasar modal).

Penelitian empiris lainnya yang menggunakan data individual antara lain adalah penelitian Bergman dan Nevarez (2006) yang meneliti tentang pengaruh pemeriksaan pajak terhadap kepatuhan Wajib Pajak dalam konteks Pajak Pertambahan Nilai di Chile dan Argentina, penelitian Gemmell dan Ratto (2012) yang meneliti tentang respon Wajib Pajak setelah dilakukan pemeriksaan pajak di Inggris dan penelitian DeBacker et al. (2013) yang mengukur agresivitas pajak Wajib Pajak setelah Pemeriksaan pajak di Amerika Serikat. Selain itu, penelitian empiris lainnya yang menggunakan data individual adalah penelitian Almunia dan Lopez-Rodriguez (2014) yang meneliti tentang respon Wajib Pajak terhadap pemeriksaan pajak yang dilakukan di Spanyol, dan penelitian Advani, Elming, dan Shaw (2015) yang mengukur seberapa lama pengaruh pemeriksaan pajak bertahan pada Wajib Pajak.

\subsection{Pengaruh pemeriksaan pajak terhadap kepatuhan Wajib Pajak}

Dalam information note yang diterbitkan pada tahun 2004 dan berjudul "Compliance Risk Management: Audit Case Selection Systems", OECD menjelaskan bahwa pengaruh pemeriksaan pajak terhadap kepatuhan Wajib Pajak dapat dibedakan menjadi dua bentuk yaitu pengaruh langsung (direct effect) dan pengaruh tidak langsung (indirect effect). Pengaruh langsung dapat berupa tambahan setoran pajak, bunga, maupun sanksi denda yang merupakan hasil dari temuan pemeriksaan. Adapun pengaruh tidak langsung dapat dibagi menjadi tiga yaitu:

1. Corrective effect.
Pengaruh tidak langsung yang dirasakan oleh Wajib Pajak yang diperiksa sehingga Wajib Pajak tersebut akan meningkatkan kepatuhannya di masa yang akan datang.

2. Deterrent effect.

Pengaruh tidak langsung yang dirasakan oleh Wajib Pajak di sekeliling Wajib Pajak sehingga Wajib Pajak lain tersebut akan ikut serta menjadi lebih patuh di masa yang akan dating.

3. Indirect preventive effect.

Pengaruh tidak langsung berupa pencegahan kepada Wajib Pajak lain yang tidak diperiksa sehingga Wajib Pajak tersebut tidak melakukan pelanggaran yang sama dengan Wajib Pajak yang diperiksa.

Penjelasan OECD ini senada dengan klasifikasi lainnya yang digunakan oleh Alm, Jackson, McKee (2009) dan Gemmel dan Ratto (2012) meskipun menggunakan istilah yang berbeda. Alm, Jackson, dan McKee (2009) menggunakan istilah direct deterrent effect untuk corrective effect dan indirect deterrent effect untuk deterrent effect dan indirect preventive effect sedangkan Gemmel dan Ratto (2012) lebih menyukai istilah spillover effect untuk mengacu pada deterrent effect.

Selain klasifikasi yang telah dijelaskan sebelumnya, beberapa peneliti telah menemukan beberapa pengaruh lain dari pemeriksaan pajak terhadap kepatuhan Wajib Pajak. Pengaruh-pengaruh tersebut antara lain bomb-crater effect dan echo effect yang dikemukakan dalam Guala dan Mittone (2005) dan Mittone (2006).

Bomb-crater effect dapat dijelaskan dengan baik dengan ilustrasi berikut yaitu ketika terjadi Perang Dunia Kedua, para tentara yang berperang akan merasa aman berada di sekitar bekas tempat jatuhnya bom karena merasa tidak mungkin sebuah bom dapat jatuh di tempat yang persis sama pada saat bom berikutnya dilemparkan. Dengan mengacu pada ilustrasi tersebut, bomb-crater effect dapat dijelaskan dengan rasa aman yang dialami oleh Wajib Pajak setelah diperiksa karena Wajib Pajak akan merasa tidak mungkin diperiksa lagi dalam waktu dekat sehingga Wajib Pajak dapat menurunkan tingkat kepatuhan Wajib Pajak langsung setelah pemeriksaan selesai dilaksanakan. Berdasarkan penelitian lanjutan yang dilakukan oleh Maciejovsky, Kirchler, dan Schwarzenberger (2007), bomb-crater effect ini juga dapat timbul karena adanya upaya Wajib Pajak untuk segera mengembalikan kerugian yang diperoleh karena hasil pemeriksaan pajak yang baru saja dialami oleh Wajib Pajak tersebut atau dapat juga dikenali dengan istilah compensation effect dalam penelitian Bergman dan Nevarez (2006).

Sementara itu, echo effect dapat diartikan sebagai pengaruh yang tertinggal dalam diri Wajib Pajak dalam beberapa waktu setelah Pemeriksaan pajak selesai dilaksanakan seperti diilustrasikan sebagai suara berdenging yang masih tertinggal di kepala seorang tentara setelah adanya ledakan bom disekelilingnya. Echo effect akan bertahan lama apabila pemeriksaan pajak yang dilakukan berulang-ulang. Lebih lanjut 
dengan pengembangan yang dilakukan dalam penelitian Kastlunger et al. (2009) diperoleh kesimpulan bahwa jika terjadi pemeriksaan pajak terus menerus di awal "masa hidup pajak" suatu Wajib Pajak, Wajib Pajak tersebut akan cenderung untuk menjadi lebih patuh dalam masa yang akan datang, sebaliknya jika Wajib Pajak mengalami "kekosongan" pemeriksaan pajak dalam jangka waktu yang lama maka jika dilakukan pemeriksaan pajak pada "masa hidup pajak" yang sudah cukup lanjut, Wajib Pajak tersebut tidak akan menjadi lebih patuh setelah pemeriksaan pajak selesai dilaksanakan.

Pengaruh pemeriksaan pajak terhadap kepatuhan Wajib Pajak lainnya dapat ditemukan dalam penelitian Hashimzade et al. (2014) yang memperkenalkan istilah target effect yaitu pengaruh pemeriksaan pajak yang menjadikan Wajib Pajak merasa diawasi dan berada di bawah "radar pengawasan" otoritas perpajakan segera setelah pemeriksaan pajak selesai dilaksanakan sehingga Wajib Pajak tersebut akan meningkatkan kepatuhan Wajib Pajak di masa yang akan datang. Pengaruh pemeriksaan pajak ini kemudian dijelaskan sebagai sebuah proses type-updating atau pembaharuan jenis risiko yang diyakini oleh Wajib Pajak dalam penelitian DeBacker et al. (2013). Dalam proses pembaharuan risiko ini, Wajib Pajak yang sebelumnya menetapkan risiko sebesar $A$ kemudian setelah pemeriksaan pajak merasakan kerugian yang diperoleh lebih besar dari A akan terkena target effect sedangkan sebaliknya jika setelah pemeriksaan pajak kerugian yang dirasakan oleh Wajib Pajak lebih kecil dari A maka Wajib Pajak akan cenderung untuk menurunkan kepatuhannya segera setelah pemeriksaan pajak selesai dilaksanakan.

Lebih lanjut dalam penelitian Bergman dan Navarez (2006) dijelaskan beberapa kemungkinan reaksi yang dapat dilakukan Wajib Pajak setelah pemeriksaan pajak selesai dilaksanakan adalah sebagai berikut:

1. Wajib Pajak dapat merasakan bahwa kemungkinan untuk dapat diperiksa kembali meningkat sehingga Wajib Pajak akan meningkatkan tingkat kepatuhan Wajib Pajak.

2. Wajib Pajak dapat merasakan bahwa kemungkinan untuk diperiksa kembali justru lebih rendah sehingga Wajib Pajak akan menurunkan tingkat kepatuhan Wajib Pajak.

3. Wajib Pajak dapat merasakan bahwa pemeriksaan pajak merupakan pengalaman yang traumatis sehingga Wajib Pajak akan meningkatkan tingkat kepatuhan Wajib Pajak.

4. Wajib Pajak dapat merasakan bahwa pemeriksaan pajak tidak seperti yang selama ini dibayangkan (dalam artian lebih ringan) sehingga Wajib Pajak akan menurunkan tingkat kepatuhan Wajib Pajak.

5. Wajib Pajak dapat merasakan bahwa setelah dilaksanakan pemeriksaan Wajib Pajak akan berada dalam pengawasan otoritas perpajakan sehingga Wajib Pajak akan meningkatkan tingkat Kepatuhan Wajib Pajak.

Wajib Pajak dapat merasakan bahwa kemampuan deteksi otoritas perpajakan tidak terlalu baik sehingga
Wajib Pajak akan menurunkan tingkat kepatuhan Wajib Pajak.

\subsection{Hasil Penelitian Terdahulu}

Beberapa penelitian empiris terdahulu yang berkaitan dengan pengaruh pemeriksaan pajak terhadap kepatuhan Wajib Pajak setelah dilaksanakan pemeriksaan pajak yang Peneliti ketahui antara lain:

1. Marcelo Bergman dan Armando Nevarez (2006) dalam penelitian berjudul Do Audits Enhance Compliance? An Empirical Assessment of VAT Enforcement. Dalam penelitian ini, Bergman dan Nevarez (2006) melakukan analisis terhadap data individual Wajib Pajak di Chile dan Argentina tentang pelaporan SPT Masa Pajak Pertambahan Nilai sebelum, selama, dan setelah pemeriksaan pajak dan hasil yang diperoleh dari pemeriksaan pajak seperti tambahan pajak dan sanksi denda yang harus dibayarkan untuk meneliti pengaruh pemeriksaan pajak terhadap kepatuhan Wajib Pajak setelah dilaksanakan pemeriksaan pajak.

Objek dalam penelitian ini terdiri dari dua kelompok, kelompok pertama sebagai treatment group yaitu Wajib Pajak Badan dan Orang Pribadi yang diperiksa dan kelompok kedua sebagai control group yaitu Wajib Pajak Badan dan Orang Pribadi yang tidak diperiksa namun memiliki karakteristik yang hampir mirip dengan kelompok Wajib Pajak yang diperiksa seperti berada pada daerah yang sama, menjalankan bisnis yang sejenis, dan memiliki ukuran omzet usaha yang sebanding.

Pemilihan sampel untuk treatment group menggunakan metode random sampling dengan mengecualikan Wajib Pajak yang tergolong dalam Wajib Pajak Besar sedangkan pemilihan sampel untuk control group menyesuaikan karakteristik dari treatment group. Dari hasil pemelihan sampel, untuk Argentina diperoleh 1.086 Wajib Pajak Orang Pribadi yang dimasukkan dalam treatment group dan 1.200 Wajib Pajak Orang Pribadi yang dimasukkan dalam control group, sedangkan untuk Chile diperoleh 778 Wajib Pajak Orang Pribadi yang dimasukkan dalam treatment group dan 773 Wajib Pajak Orang Pribadi yang dimasukkan dalam control group.

Dalam melakukan analisisnya, Bergman dan Nevarez (2006) menggunakan dua metode yaitu statistik deskriptif dan analisis regresi multivariat dengan menggunakan Ordinary Least Squares (OLS). Untuk statistik deskriptif, Bergman dan Nevarez (2006) menggunakan D/C ratio yang merupakan rasio Pajak Keluaran yang dipungut Wajib Pajak dari pembeli dengan Pajak Masukan yang dibayarkan Wajib Pajak sebelumnya. Berdasarkan statistik deskriptif diperoleh kesimpulan bahwa $\mathrm{D} / \mathrm{C}$ ratio meningkat selama pemeriksaan pajak berlangsung namun setelah pemeriksaan pajak selesai dilaksanakan, D/C ratio menurun dalam tingkat yang lebih rendah dari $D / C$ ratio Wajib Pajak sebelum dilaksanakan pemeriksaan pajak. Untuk analisis regresi 
multivariat, Bergman dan Nevarez (2006) menggunakan persentase perubahan pembayaran pajak sebagai variabel dependen dan logaritma hasil pemeriksaan, logaritma jumlah penjualan Wajib Pajak, selisih penjualan Wajib Pajak, dan tiga dummy variabel berupa daerah, Wajib Pajak Patuh, dan pembayaran sebelumnya sebagai variabel independen. Hasil regresi menunjukkan setiap penambahan log unit hasil pemeriksaan akan menurunkan persentase perubahan pembayaran pajak sebesar 3\% untuk Chile dan 6,7\% untuk Argentina. Bergman dan Nevarez (2006) kemudian menyimpulkan bahwa pemeriksaan pajak cenderung memberikan pengaruh negatif terhadap kepatuhan Wajib Pajak setelah pemeriksaan pajak selesai dilaksanakan.

2. Yongzhi Niu (2010) dalam penelitian berjudul Tax Audit Impact on Voluntary Compliance. Dalam penelitian ini, Niu (2010) melakukan analisis terhadap data individual Wajib Pajak di negara bagian New York, Amerika Serikat tentang pelaporan SPT Tahunan Pajak Penjualan (Sales Tax) setelah pemeriksaan pajak dan pemeriksaan pajak untuk meneliti pengaruh pemeriksaan pajak terhadap kepatuhan Wajib Pajak setelah dilaksanakan pemeriksaan pajak. Objek dalam penelitian ini terdiri dari dua kelompok, kelompok pertama sebagai treatment group yaitu Wajib Pajak yang diperiksa dan kelompok kedua sebagai control group yaitu Wajib Pajak yang tidak diperiksa. Wajib Pajak dalam penelitian ini merupakan Wajib Pajak Badan yang termasuk dalam klasifikasi lapangan usaha Jasa Tempat Makanan dan Minuman (NAICS 772). Niu menggunakan seluruh populasi Wajib Pajak dalam klasifikasi lapangan usaha tersebut yang berjumlah 6.886 Wajib Pajak. Dengan menggunaan kriteria pemeriksaan pajak yang dilakukan diperoleh 1.955 Wajib Pajak Badan yang dimasukkan dalam treatment group yang kemudian dikelompokkan berdasarkan tahun dimulainya pemeriksaan pajak dari tahun 2003 hingga tahun 2008 dan 4.931 Wajib Pajak Badan yang dimasukkan dalam control group yang sama sekali tidak pernah diperiksa.

Dalam melakukan analisisnya, Niu (2010) menggunakan pendekatan difference-indifferences non-experimental dengan menggunakan dua metode yaitu Pooled Least Squares (PLS) dan first-order Autoregressive model (Parks Method). Meskipun memiliki data individual Wajib Pajak, Niu (2010) memilih untuk menggunakan data aggregat dari Wajib Pajak tersebut dengan mengelompokkan Wajib Pajak per tahun dimulainya pemeriksaan dan Wajib Pajak yang sama sekali tidak dilakukan pemeriksaan pajak. Untuk Pooled Least Squares (PLS), Niu (2010) menggunakan selisih tingkat pertumbuhan penjualan Wajib Pajak antara kelompok yang diperiksa dengan kelompok yang tidak diperiksa sebagai variabel dependen sedangkan dummy pemeriksaan pajak sebagai variabel independen sedangkan untuk first-order Autoregressive model (Parks Method) Niu menggunakan variabel dependen dan independen yang sama dengan menambahkan tingkat pertumbuhan total gaji di negara bagian New York sebagai variabel instrumen. Dari kedua regresi tersebut, Niu (2010) mendapatkan hasil berupa nilai koefisien untuk dummy pemeriksaan pajak masing-masing sebesar $2,72 \%$ dan $2,63 \%$ dan memberikan kesimpulan bahwa setelah dilakukan pemeriksaan pajak, kelompok Wajib Pajak yang diperiksa akan melaporkan pertumbuhan tingkat penjualan yang lebih tinggi sekitar 2,63\% dibandingkan dengan kelompok Wajib Pajak yang tidak diperiksa sehingga pemeriksaan pajak memberikan pengaruh positif terhadap kepatuhan Wajib Pajak setelah dilaksanakan pemeriksaan pajak.

3. Norman Gemmel dan Marissa Ratto (2012) dalam penelitian berjudul Behavioral Responses To Taxpayer Audits: Evidence From Random Taxpayer Inquiries.Dalam penelitian ini, Gemmel dan Ratto (2012) melakukan analisis terhadap data individual Wajib Pajak di Inggris tentang pelaporan SPT Tahunan Pajak Penghasilan sebelum dan setelah pemeriksaan pajak yang dilakukan dengan strategi pemeriksaan random audit untuk meneliti pengaruh pemeriksaan pajak terhadap kepatuhan Wajib Pajak setelah dilaksanakan pemeriksaan pajak.

Objek dalam penelitian ini terdiri dari dua kelompok, kelompok pertama sebagai treatment group yaitu Wajib Pajak Orang Pribadi yang diperiksa dan kelompok kedua sebagai control group yaitu Wajib Pajak Orang Pribadi yang tidak diperiksa, treatment group kemudian dibagi menjadi dua sub-kelompok yaitu Wajib Pajak patuh dan Wajib Pajak tidak patuh. Wajib Pajak dalam penelitian ini merupakan Wajib Pajak Orang Pribadi yang tergolong dalam segmentasi small business, medium business, dan personal yang merupakan objek dari strategi pemeriksaan random audit yang dilaksanakan oleh otoritas perpajakan Inggris. Wajib Pajak dalam treatment group dipilih dari Wajib Pajak dari segmen small business, medium business, dan personal yang diperiksa pada tahun 2000 sedangkan Wajib Pajak dalam control group dipilih dengan menggunakan metode random sampling dengan karakteristik yang mirip dengan Wajib Pajak dalam treatment group. Untuk menghindari tercampurnya pengaruh Pemeriksaan pajak tahun 2000 dengan Pemeriksaan pajak tahun sebelum dan sesudahnya, Wajib Pajak yang telah diperiksa pada tahun 1997-1999 dan 2001-2003 dikeluarkan dari objek penelitian, sehingga akhirnya didapatkan objek dalam treatment group sebanyak 2.006 Wajib Pajak dan objek dalam control group sebanyak 6.420 Wajib Pajak. Kriteria Wajib Pajak patuh atau tidak patuh didapatkan dari hasil 
Pemeriksaan pajak dimana jika setelah pemeriksaan pajak terdapat koreksi tambahan pajak maka Wajib Pajak dimasukkan dalam kategori Wajib Pajak tidak patuh sedangkan sebaliknya jika setelah pemeriksaan pajak tidak terdapat koreksi maka Wajib Pajak dimasukkan dalam kategori Wajib Pajak patuh.

Dalam melakukan analisisnya, Gemmel dan Ratto (2012) menggunakan pendekatan difference-in-differences dengan menggunakan regresi Ordinary Least Squares (OLS). Variabel dependen yang digunakan adalah jumlah pajak yang dilaporkan dan variabel independen yang digunakan adalah empat dummy variabel yaitu pemeriksaan, waktu, Wajib Pajak patuh dan Wajib Pajak tidak patuh. Hasil regresi menunjukkan bahwa setelah dilaksanakan pemeriksaan pajak, Wajib Pajak patuh justru akan menunjukkan penurunan jumlah pajak yang dilaporkan dalam rentang $7 \%$ hingga $17 \%$ dari jumlah pelaporan pajak sebelum pemeriksaan pajak sedangkan Wajib Pajak tidak patuh akan menunjukkan kenaikan jumlah pajak yang dilaporkan dalam rentang $5 \%$ hingga $24 \%$ dari jumlah pelaporan pajak sebelum pemeriksaan pajak. Gemmel dan Ratto (2012) kemudian menyimpulkan bahwa pemeriksaan pajak akan menimbulkan pengaruh terhadap kepatuhan Wajib Pajak setelah pemeriksaan pajak selesai dilaksanakan yang berbeda untuk jenis Wajib Pajak yang berbeda dimana akan cenderung memberikan pengaruh negatif untuk Wajib Pajak patuh namun akan memberikan pengaruh positif untuk Wajib Pajak tidak patuh.

4. Jason DeBacker et al. (2013) dalam penelitian berjudul The Impact of Legal Enforcement: An Analysis of Corporate Tax Aggressiveness after an Audit. Dalam penelitian ini, DeBacker et al. (2013) melakukan analisis terhadap data individual Wajib Pajak di Amerika Serikat tentang pelaporan SPT Tahunan Pajak Penghasilan sebelum, selama, dan setelah pemeriksaan pajak untuk meneliti pengaruh pemeriksaan pajak terhadap agresivitas pajak (tax agressiveness) setelah dilaksanakan pemeriksaan pajak. Objek dalam penelitian DeBacker et al. (2013) terdiri dari seluruh Wajib Pajak Badan di Amerika Serikat yang kemudian dipisahkan antara Wajib Pajak Badan yang pernah mengalami pemeriksaan pajak dari tahun 1996 2011 sebanyak 8.482.514 Wajib Pajak dan Wajib Pajak Badan yang belum pernah mengalami pemeriksaan pajak sebanyak 8.491.730 Wajib Pajak.

Dalam melakukan analisisnya, DeBacker et al. (2013) menggunakan analisis regresi dengan menggunakan model Ordinary Least Squares (OLS). Variabel dependen yang digunakan adalah tarif pajak efektif (effective tax rate/ETR) dengan variabel independen berupa dummy pemeriksaan pajak terakhir kali dan variabel kontrol berupa karakteristik Wajib Pajak Badan seperti logaritma total aset, persediaan, dan tiga dummy status perusahaan yaitu kepemilikan asing, publik/privat, dan multinasional/nasional.

Hasil regresi menunjukkan bahwa pada saat pemeriksaan pajak sedang berlangsung tarif pajak efektif Wajib Pajak Badan akan mengalami peningkatan sekitar 2,52\% namun segera setelah pemeriksaan pajak selesai dilaksanakan tarif pajak efektif Wajib Pajak Badan akan mengalami penurunan sekitar $3 \%$ dan terus mengalami penurunan hingga mencapai $12 \%$ pada akhir tahun kelima setelah pemeriksaan pajak dan kemudian perlahan-lahan mengalami kenaikan hingga stabil pada tingkat $8 \%$ lebih rendah dari tarif pajak efektif sebelum dilaksanakan pemeriksaan pajak. DeBacker et al. (2013) kemudian menyimpulkan bahwa pemeriksaan pajak cenderung memberikan pengaruh negatif terhadap kepatuhan Wajib Pajak setelah pemeriksaan pajak selesai dilaksanakan.

Penelitian terdahulu memberikan dua kesimpulan yang berbeda bahwa pemeriksaan pajak dapat memberikan pengaruh yang negatif namun juga dapat memberikan pengaruh yang positif terhadap kepatuhan Wajib Pajak setelah pemeriksaan pajak selesai dilaksanakan. Oleh karena itu, Peneliti tertarik untuk melakukan penelitian mengenai pengaruh pemeriksaan pajak terhadap kepatuhan Wajib Pajak setelah dilaksanakan pemeriksaan pajak dengan menggunakan objek Wajib Pajak Badan di Indonesia dalam konteks Pajak Penghasilan.

Untuk itu Peneliti mengadopsi penelitian yang dilakukan oleh Gemmel dan Ratto (2012) dengan melakukan beberapa modifikasi untuk menyesuaikan dengan kondisi pemeriksaan pajak di Indonesia seperti adanya dua jenis pemeriksaan pajak yang umum di Indonesia yaitu pemeriksaan rutin dan pemeriksaan khusus sehingga kedua jenis pemeriksaan ini akan diuji pengaruhnya terhadap kepatuhan Wajib Pajak setelah dilaksanakan pemeriksaan pajak.

Pengujian pengaruh pemeriksaan pajak ini akan dilakukan berturut-turut untuk keseluruhan Wajib Pajak Badan dan untuk Wajib Pajak Badan yang terdaftar pada masing-masing jenis Kantor Pelayanan Pajak (KPP), yaitu KPP Pratama, KPP Madya, serta KPP Wajib Pajak Besar dan KPP Khusus. Jenis KPP mengacu pengertian sebagai berikut:

- KPP Pratama mengurusi Wajib Pajak Orang Pribadi atau Badan yang memiliki penghasilan, selain Wajib Pajak yang diadministrasikan oleh KPP Madya, KPP Wajib Pajak Besar, dan KPP Khusus.

- KPP Madya mengurusi Wajib Pajak badan yang memiliki penghasilan cukup besar di wilayah kabupaten/kota, selain yang diadministrasikan oleh KPP Wajib Pajak Besar.

- KPP Wajib Pajak Besar adalah KPP yang menangani Wajib Pajak dengan peredaran usaha yang paling besar dan kriteria tertentu lainnya, dan hanya mengadministrasikan jenis pajak PPh dan PPN.

- KPP Khusus meliputi KPP BUMN, Perusahaan Penanaman Modal Asing (PMA), WP Badan dan 
Orang Asing serta perusahaan yang tercatat di Bursa Efek Indonesia (BEI).

\subsection{Hipotesis Penelitian}

Berdasarkan teori yang dikemukakan maka hipotesis yang akan diajukan oleh Peneliti dalam penelitian ini adalah sebagai berikut:

Ho: Setelah dilakukan pemeriksaan pajak, tidak terdapat perbedaan tingkat kepatuhan antara Wajib Pajak Badan di Indonesia yang mengalami pemeriksaan pajak dengan Wajib Pajak Badan yang tidak mengalami pemeriksaan pajak.

Ha: Setelah dilakukan pemeriksaan pajak, terdapat perbedaan tingkat kepatuhan antara Wajib Pajak Badan di Indonesia yang mengalami pemeriksaan pajak dengan Wajib Pajak Badan yang tidak mengalami pemeriksaan pajak.

\section{METODE PENELITIAN}

\subsection{Data}

Data yang digunakan dalam penelitian ini adalah data sekunder dalam bentuk data panel yang berupa data isian dari Surat Pemberitahuan (SPT) Tahunan Pajak Penghasilan Wajib Pajak Badan dan data administrasi pemeriksaan. Data isian SPT Tahunan terdiri dari jenis klasifikasi lapangan usaha (KLU), jumlah peredaran usaha, jumlah penghasilan kena pajak, dan jumlah Pajak Penghasilan (PPh) Terutang untuk tahun pajak 2009-2013 sedangkan data administrasi pemeriksaan Wajib Pajak terdiri dari jenis pemeriksaan, tanggal Surat Pemberitahuan Pemeriksaan (SP2) sebagai tanggal awal dimulainya pemeriksaan, dan tanggal Laporan Hasil Pemeriksaan sebagai tanggal pemeriksaan pajak berakhir. Semua data yang digunakan diperoleh dari Direktorat Jenderal Pajak.

Populasi dalam penelitian ini adalah Wajib Pajak Badan yang terdaftar dalam basis data DJP. Berdasarkan Laporan Tahunan DJP tahun 2012 jumlah Wajib Pajak Badan yang terdaftar selama tahun 2009 hingga 2012 terus mengalami peningkatan meskipun demikian tidak semua Wajib Pajak Badan yang terdaftar wajib menyampaikan SPT Tahunan PPh Badan dan tidak semua Wajib Pajak yang wajib menyampaikan SPT Tahunan PPh Badan benar-benar menyampaikan SPT Tahunan PPh Badan.

Dari data yang tersedia tersebut, digunakan metode pemilihan sampel sesuai dengan metode purposive sampling. Metode purposive sampling adalah metode penentuan sampel dengan menggunakan kriteria yang ditentukan oleh peneliti (Sekaran, 2003: 277). Kriteria-kriteria yang digunakan adalah sebagai berikut:

1. Wajib Pajak yang terdaftar pada tahun 2009 hingga tahun 2013.

2. Wajib Pajak memiliki data yang lengkap berupa jumlah peredaran usaha, jumlah pendapatan kena pajak, dan jumlah PPh terutang untuk setiap tahun dari tahun 2009-2013.
3. Kemudian Wajib Pajak dipisahkan menjadi dua kelompok yaitu kelompok treatment dan kelompok control dimana:

a. Untuk kelompok treatment, Wajib Pajak pernah mengalami satu kali pemeriksaan pajak pada tahun 2011.

b. Untuk kelompok control, Wajib Pajak tidak pernah mengalami pemeriksaan pajak dalam rentang waktu 2009-2013.

\subsection{Model Penelitian}

Data yang digunakan dalam penelitian ini adalah data sekunder dalam bentuk data panel yang berupa data isian dari Surat Pemberitahuan (SPT) Tahunan Pajak Penghasilan

Sesuai dengan tujuan penelitian ini untuk mendapatkan perbedaan tingkat kepatuhan Wajib Pajak setelah dilakukan pemeriksaan pajak, model penelitian yang akan digunakan dalam penelitian ini menggunakan pendekatan difference-in-differences (DID). Lechner (2011) mengungkapkan bahwa pendekatan DID merupakan desain penelitian untuk menemukan pengaruh kausal yang cukup populer dalam penelitian ekonomi empiris untuk melakukan estimasi pengaruh dari intervensi kebijakan dan perubahan kebijakan yang tidak berpengaruh terhadap semua orang dalam waktu yang sama dan dengan cara yang sama. Lechner (2011) menambahkan bahwa pendekatan DID merupakan pilihan yang cukup atraktif dibandingkan dengan penggunaan desain penelitian yang menggunakan variabel kontrol maupun variabel instrumen yang seringkali sulit untuk didapatkan.

Lechner (2011) kemudian mengungkapkan bahwa terdapat beberapa asumsi yang harus dipenuhi agar pendekatan DID dapat digunakan. Beberapa asumsi tersebut dapat dijelaskan sebagai berikut:

1. Hasil potensial yang diharapkan harus dapat diobservasi untuk setiap anggota dari populasi yang akan diteliti. Asumsi ini seringkali disebut juga dengan aturan observasi atau dapat juga disebut dengan Stable Unit Treatment Value (Rubin, 1977 dalam Lechner, 2011).

2. Terdapat eksogenitas dalam variabel independen.

3. Pelaksanaan kebijakan tidak memberikan pengaruh terhadap populasi pada periode sebelum kebijakan dilaksanakan.

4. Baik kelompok treatment group maupun kelompok control memiliki trend yang sama jika tidak terjadi pelaksanaan kebijakan. Asumsi ini sering disebut dengan common trend atau bias stability dan merupakan asumsi kunci dalam pendekatan DID.

5. Asumsi common trend atau bias stability sangat tergantung pada bentuk fungsional dari variabel dependen atau variabel hasil yang diharapkan sehingga pemilihan bentuk fungsional dari variabel dependen menjadi poin kritis yang perlu diperhatikan oleh peneliti. Hal ini seringkali disebut menjadi salah satu kekurangan dari pendekatan DID. 
Model pendekatan DID yang digunakan dalam penelitian ini mengacu pada penelitian Norman Gemmell dan Marissa Ratto (2012) tentang perubahan perilaku yang ditunjukkan oleh sekelompok Wajib Pajak Orang Pribadi di Inggris dalam melaporkan Pajak Penghasilan setelah dilaksanakan pemeriksaan pajak secara random audit kepada Wajib Pajak tersebut dibandingkan dengan kelompok Wajib Pajak Orang Pribadi yang tidak diperiksa sama sekali. Penggunaan model pendekatan DID ini didasarkan pada kesamaan jenis pajak yang diteliti yaitu Pajak Penghasilan namun dalam konteks yang berbeda dengan menggunakan objek penelitian Wajib Pajak Badan di Indonesia. Perbedaan lainnya juga terletak pada jenis Pemeriksaan Pajak yang digunakan, jika dalam penelitian Gemmell dan Ratto (2012) menggunakan random audit maka dalam konteks penelitian ini akan digunakan pemeriksaan pajak yang terdapat di Indonesia yaitu pemeriksaan untuk menguji kepatuhan Wajib Pajak yang terdiri dari pemeriksaan rutin dan pemeriksaan khusus yang merupakan risk-based audit.

Mengadopsi Gemmell dan Ratto (2012), persamaan regresi DID pertama yang digunakan untuk mengetahui pengaruh pemeriksaan secara keseluruhan baik pemeriksaan rutin maupun pemeriksaan khusus adalah:

$y_{i t}=\beta_{0}+\beta_{1} D_{T}+\beta_{2} D_{G}+\alpha D_{G} . D_{T}+\varepsilon_{i t}$ (1)

dimana:

$i=$ Wajib Pajak

$t=$ Waktu

$y=$ Pajak Penghasilan terutang

$D_{T}=$ Variabel dummy waktu

(=0 untuk sebelum tahun 2011, =1 untuk setelah tahun 2011)

$D_{G}=$ Variabel dummy grup

( $=0$ untuk kelompok control, $=1$ untuk kelompok treatment, Wajib Pajak yang mengalami pemeriksaan pajak baik pemeriksaan rutin maupun pemeriksaan khusus pada tahun 2011)

$\varepsilon_{\mathrm{it}}=$ Error.

Koefisien regresi DID dapat diinterprestasikan sebagai berikut:

$\beta_{0}=$ rata-rata hasil yang diharapkan untuk control group sebelum tahun 2011.

$\beta_{1}=$ perbedaan rata-rata hasil yang diharapkan sebelum dan sesudah tahun2011

$\beta_{2}=$ perbedaan rata-rata hasil yang diharapkan antara kelompok control dan

kelompok treatment sebelum dilaksanakan pemeriksaan pajak

$\alpha=$ perbedaan perubahan hasil yang diharapkan dari kelompok treatment terhadap

kelompok control.

Untuk mengetahui pengaruh masing-masing dari pemeriksaan rutin dan pemeriksaan khusus, variabel dummy grup kemudian dibedakan menjadi variabel dummy pemeriksaan rutin dan variabel dummy pemeriksaan khusus sehingga persamaan regresi DID (1) disesuaikan menjadi sebagai berikut: $y_{i t}=\beta_{0}+\beta_{1} D_{T}+\alpha_{1} D_{R} \cdot D_{T}+\alpha_{2} D_{K} \cdot D_{T}+\gamma_{i}+\varepsilon_{i t}(2)$

dimana:

$i=$ Wajib Pajak.

$t=$ Waktu.

$y=$ Pajak Penghasilan terutang.

$D_{T}=$ Variabel dummy waktu

(=0 untuk sebelum tahun 2011 , =1 untuk setelah tahun 2011)

$D_{R}=$ Variabel dummy pemeriksaan rutin

(=1 untuk Wajib Pajak yang diperiksa dengan pemeriksaan rutin pada tahun 2011,

$=0$ untuk Wajib Pajak lain)

$D_{K}=$ Variabel dummy pemeriksaan khusus

(=1 untuk Wajib Pajak yang diperiksa dengan pemeriksaan khusus pada tahun 2011, $=0$ untuk Wajib Pajak lain)

$\gamma=$ fixed-effect individual

$\varepsilon_{\text {it }}=$ Error.

Dalam persamaan regresi DID kedua ini, koefisien regresi DID dapat diinterprestasikan sebagai berikut: $\alpha_{1}=$ perbedaan rata-rata Pajak Penghasilan Terutang dari Wajib Pajak yang mengalami pemeriksaan rutin terhadap seluruh Wajib Pajak yang tidak mengalami pemeriksaan.

$\alpha_{2}=$ perbedaan rata-rata Pajak Penghasilan Terutang dari Wajib Pajak yang mengalami pemeriksaan khusus terhadap seluruh Wajib Pajak yang tidak mengalami pemeriksaan.

Dalam penelitian ini variabel dependen yang digunakan sama dengan variabel dependen yang digunakan dalam penelitian Gemmell dan Ratto (2012) yaitu Pajak Penghasilan terutang. Sedangkan variabel independen yang digunakan dalam penelitian ini adalah variabel dummy yang terdiri dari variabel dummy grup, variabel dummy waktu, variabel dummy pemeriksaan rutin, dan variabel dummy pemeriksaan khusus. Penjelasan atas variabel-variabel yang digunakan dalam penelitian ini adalah sebagai berikut:

\section{Pajak Penghasilan terutang}

Mengadopsi penelitian Gemmell dan Ratto (2012), Pajak Penghasilan terutang yang dilaporkan digunakan sebagai variabel yang mencerminkan kepatuhan sukarela dari Wajib Pajak. Dalam penelitian ini data pajak penghasilan terutang kena pajak diperoleh dari Surat Pemberitahuan (SPT) Tahunan Pajak Penghasilan (PPh) Badan yang dilaporkan kepada Direktorat Jenderal Pajak. Pajak Penghasilan Terutang diukur dengan menggunakan dua nilai yaitu dengan menggunakan nilai rupiah yang disesuaikan dengan tingkat inflasi yang dirilis oleh Biro Pusat Statistik (BPS) dengan tahun 2009 sebagai tahun dasar dan nilai logaritma natural dari nilai rupiah tersebut. Kedua nilai ini akan dipilih salah satunya yang dapat memenuhi uji asumsi common trend yang akan dilakukan kemudian. 


\section{Grup}

Variabel dummy grup merupakan variabel yang digunakan untuk membedakan Wajib Pajak apakah Wajib Pajak tersebut termasuk dalam treatment group yaitu Wajib Pajak yang mengalami pemeriksaan pajak pada tahun 2011 baik dengan pemeriksaan rutin maupun pemeriksaan khusus atau termasuk dalam control group yaitu Wajib Pajak yang tidak mengalami pemeriksaan pajak. Variabel dummy grup bernilai 1 untuk Wajib Pajak yang mengalami pemeriksaaan pajak sedangkan untuk Wajib Pajak yang tidak mengalami pemeriksaan pajak variabel dummy grup akan diberi nilai 0 .

\section{Waktu.}

Variabel dummy waktu merupakan variabel yang digunakan untuk membedakan waktu untuk periode sebelum dan setelah pemeriksaan pajak dilaksanakan. Penelitian ini menggunakan pemeriksaan pajak yang dilaksanakan pada tahun 2011, sehingga periode waktu sebelum tahun 2011, yaitu tahun 2009 dan 2010 akan diberi nilai 0 sedangkan waktu setelah tahun 2011, yaitu tahun 2012 dan 2013 akan diberi nilai 1.

\section{Pemeriksaan Rutin}

Variabel dummy pemeriksaan rutin merupakan variabel dummy yang digunakan dalam persamaan regresi DID kedua untuk mengetahui pengaruh masingmasing dari pemeriksaan rutin dan pemeriksaan khusus. Variabel dummy ini akan digunakan untuk membedakan Wajib Pajak apakah Wajib Pajak tersebut termasuk dalam Wajib Pajak yang diperiksa pada tahun 2011 dengan pemeriksaan rutin atau tidak. Variabel dummy pemeriksaan rutin bernilai 1 untuk Wajib Pajak yang diperiksa dengan pemeriksaan rutin sedangkan untuk Wajib Pajak lainnya diberi nilai 0.

\section{Pemeriksaan Khusus}

Variabel dummy pemeriksaan khusus merupakan variabel dummy yang digunakan dalam persamaan regresi DID kedua untuk mengetahui pengaruh masingmasing dari pemeriksaan rutin dan pemeriksaan khusus. Variabel dummy ini akan digunakan untuk membedakan Wajib Pajak apakah Wajib Pajak tersebut termasuk dalam Wajib Pajak yang diperiksa pada tahun 2011 dengan pemeriksaan khusus atau tidak. Variabel dummy pemeriksaan khusus bernilai 1 untuk Wajib Pajak yang mengalami pemeriksaan khusus sedangkan untuk Wajib Pajak lainnya diberi nilai 0.

\section{HASIL PENELITIAN DAN PEMBAHASAN}

\subsection{Sampeldata}

Populasi yang akan digunakan dalam penelitian ini adalah seluruh Wajib Pajak Badan yang terdaftar dalam Sistem Informasi Direktorat Jenderal Pajak (SIDJP) dalam jangka waktu tahun 2009-2013. Berdasarkan laporan tahunan DJP tahun 2011 diketahui bahwa jumlah Wajib Pajak Badan terdaftar pada tahun 2011 adalah sebanyak 1.929.507 Wajib Pajak, dimana Wajib Pajak yang wajib menyampaikan SPT Tahunan Pajak Penghasilan (PPh) Badan sebanyak
1.590.154 Wajib Pajak. Dari jumlah tersebut, Wajib Pajak Badan yang menyampaikan SPT Tahunan PPh Badan pada tahun 2011 adalah sebanyak 520.375 Wajib Pajak.

Untuk data pemeriksaan, informasi yang dapat diperoleh dari Laporan Tahunan DJP Tahun 2011 adalah mengenai jumlah Laporan Hasil Pemeriksaan (LHP) yang diterbitkan pada tahun 2011. Berdasarkan Laporan Tahunan DJP Tahun 2011 dapat diketahui bahwa jumlah LHP terbit pada tahun 2011 adalah sebanyak 63.983 LHP dengan rincian 43.081 LHP Pemeriksaan Rutin, 4.683 LHP Pemeriksaan Khusus, dan 16.219 LHP Pemeriksaan Tujuan Lain.

Gabungan data isian SPT Tahunan PPh Badan dan data pemeriksaan yang diperoleh dalam penelitian ini adalah sebanyak 724.620 Wajib Pajak. Dari data yang diperoleh tersebut, jumlah Wajib Pajak yang menyampaikan SPT Tahunan PPh Badan bervariasi dari 415.823 Wajib Pajak pada tahun 2009 hingga mencapai 442.199 Wajib Pajak pada tahun 2012. Namun pada tahun 2013, data SPT Tahunan PPh Badan yang tersedia hanya untuk 228.406 Wajib Pajak.

Dari gabungan data yang diperoleh tersebut, dilakukan pemilihan sampel dengan beberapa kriteria sebagai berikut yaitu:

a. Wajib Pajak menyampaikan SPT Tahunan PPh Badan dalam nilai rupiah sehingga Wajib Pajak yang menyampaikan SPT Tahunan PPh Badan dalam nilai dollar Amerika Serikat dikeluarkan dari sampel penelitian,

b. Data PPh Terutang yang dilaporkan dalam SPT Tahunan setiap tahun pada tahun pajak 2009-2013 lengkap sehingga Wajib Pajak yang tidak menyampaikan atau yang tidak mengisi nilai PPh Terutang dalam SPT tahunan pada satu atau lebih tahun pajak dikeluarkan dari sampel penelitian,

c. Wajib Pajak sama sekali tidak pernah diperiksa pada rentang tahun 2009-2013 maupun tahun sebelumnya atau hanya diperiksa pada tahun 2011 sehingga Wajib Pajak yang diperiksa pada tahuntahun sebelum tahun 2011 dan tahun 2012-2013 dikeluarkan dari sampel penelitian,

d. Data PPh Terutang yang disampaikan dalam SPT Tahunan PPh Badan benar sehingga PPh Terutang yang dilaporkan dalam nilai minus dikeluarkan dari sampel penelitian, dan

e. Data PPh Terutang yang disampaikan dalam SPT Tahunan PPh Badan harus dapat diketahui nilai logaritma naturalnya untuk digunakan dalam pengujian asumsi sehingga PPh Terutang yang dilaporkan dalam angka 0 dikeluarkan dari sampel penelitian.

Setelah dilakukan filtering dengan kriteria di atas, diperoleh sampel sebanyak 16.369 Wajib Pajak, yang terdiri dari 12.179 Wajib Pajak yang terdaftar di KPP Pratama atau sekitar $74,40 \%$ dari keseluruhan sampel penelitian jumlah ini lebih rendah dari populasi keseluruhan Wajib Pajak Badan yang terdaftar di KPP Pratama yaitu sekitar lebih dari $90 \%$. Sampel penelitian yang terdaftar di KPP Madya dan KPP Wajib Pajak Besar dan KPP Khusus berturut-turut adalah sebanyak 3.573 
Wajib Pajak (21,83\% dari total sampel penelitian) dan 617 Wajib Pajak (3,77\% dari total sampel penelitian).

Secara keseluruhan perbandingan antara control group (Wajib Pajak yang tidak diperiksa) dan treatment group (Wajib Pajak yang diperiksa) adalah 96,73\% : 3,27\% dimana perbandingan untuk Wajib Pajak yang terdaftar di KPP Pratama, KPP Madya, dan KPP Wajib Pajak Besar dan KPP Khusus berturut-turut adalah $98,69 \%: 1,31 \%$, 93,25\% : 6,75\%, dan $78,28 \%: 21,72 \%$.

Hasil perhitungan statistik data penelitian dapat dilihat pada tabel di bawah ini. Berdasarkan Tabel 1 selanjutnya akan dijelaskan analisis mengenai hasil statistik deskriptif data yang digunakan dalam penelitian ini.

\begin{tabular}{|l|c|c|c|c|c|}
\hline $\begin{array}{c}\text { Variab } \\
\text { el }\end{array}$ & $\begin{array}{c}\text { Observ } \\
\text { asi }\end{array}$ & Mean & Std. Dev. & $\begin{array}{c}\text { Minimu } \\
\mathrm{m}\end{array}$ & Maximum \\
\hline adjpph & 65.476 & 15.668 .611 & 14,8922 & $\begin{array}{c}796,989 \\
9\end{array}$ & $\begin{array}{c}2.967 .230 .078 .2 \\
97\end{array}$ \\
\hline $\begin{array}{l}\text { logadj } \\
\text { pph }\end{array}$ & 65.476 & 16,56717 & 2,70084 & $\begin{array}{c}6,68084 \\
2\end{array}$ & 28,71865 \\
\hline $\mathrm{dg}$ & 65.476 & 0,0326837 & 0,1778089 & 0 & 1 \\
\hline $\mathrm{dt}$ & 65.476 & 0,5 & 0,5000038 & 0 & 1 \\
\hline $\mathrm{dr}$ & 65.476 & 0,0265135 & 0,1606579 & 0 & 1 \\
\hline $\mathrm{dk}$ & 65.476 & 0,0061702 & 0,0783085 & 0 & 1 \\
\hline
\end{tabular}

Tabel 1. Hasil Statistik Deskriptif

Sumber: Diolah dari output Stata

Pada Tabel 1 dapat kita lihat bahwa seluruh variabel memiliki jumlah observasi yang sama yaitu 65.476 data atau 16.369 data untuk masing-masing tahun. Hal tersebut menunjukkan bahwa semua data secara lengkap memiliki nilai dari tiap variabelnya sehingga dapat dilakukan analisis.

\subsection{Hasil Pengujian Data}

\section{Uji asumsi common trend}

Lechner (2011) menyebutkan bahwa asumsi kunci dalam melakukan pendekatan difference-indifferences (DID) adalah asumsi common trend atau bias stability yaitu kelompok control (dalam hal ini kelompok Wajib Pajak yang tidak mengalami pemeriksaan) dan kelompok treatment (dalam hal ini kelompok Wajib Pajak yang mengalami pemeriksaan pajak baik pemeriksaan rutin maupun pemeriksaan khusus) memiliki tren yang sama jika tidak terjadi perbedaan kebijakan antara kedua kelompok tersebut. Hal ini dapat ditunjukkan dengan melihat kesamaan tren di antara kedua kelompok tersebut sebelum dilaksanakannya kebijakan dalam hal ini pemeriksaan pajak.

Meskipun asumsi common trend ini merupakan asumsi kunci dalam melakukan pendekatan DID, asumsi ini tidak dapat diuji secara statistik. Lechner (2011) menyarankan bahwa salah satu cara untuk menguji asumsi common trend ini adalah dengan menggunakan bantuan grafik garis perubahan ratarata variabel dependen dari waktu ke waktu pada periode sebelum dilakukannya kebijakan (dalam penelitian ini adalah tahun 2009 dan tahun 2010) baik untuk kelompok control maupun kelompok treatment. Lechner (2011) kemudian menambahkan bahwa asumsi common trend ini sangat tergantung pada bentuk fungsional dari variabel dependen sehingga penting untuk melakukan pengujian asumsi common trend ini dalam bentuk fungsional yang berbeda. Dalam penelitian ini variabel dependen PPh terutang menggunakan bentuk fungsional nilai logaritma naturalnya.

Gambar 1 Uji Common Trend PPh terutang dalam nilai logaritma untuk Control Group dan Treatment Group

\section{5}

20

15

10

5

0

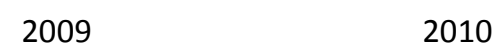

- Control Treatment

Sumber : Hasil Pengolahan Data.

Gambar 2 Uji Common Trend PPh terutang dalam nilai logaritma untuk Control Group, Kelompok Pemeriksaan Rutin dan Kelompok Pemeriksaan Khusus

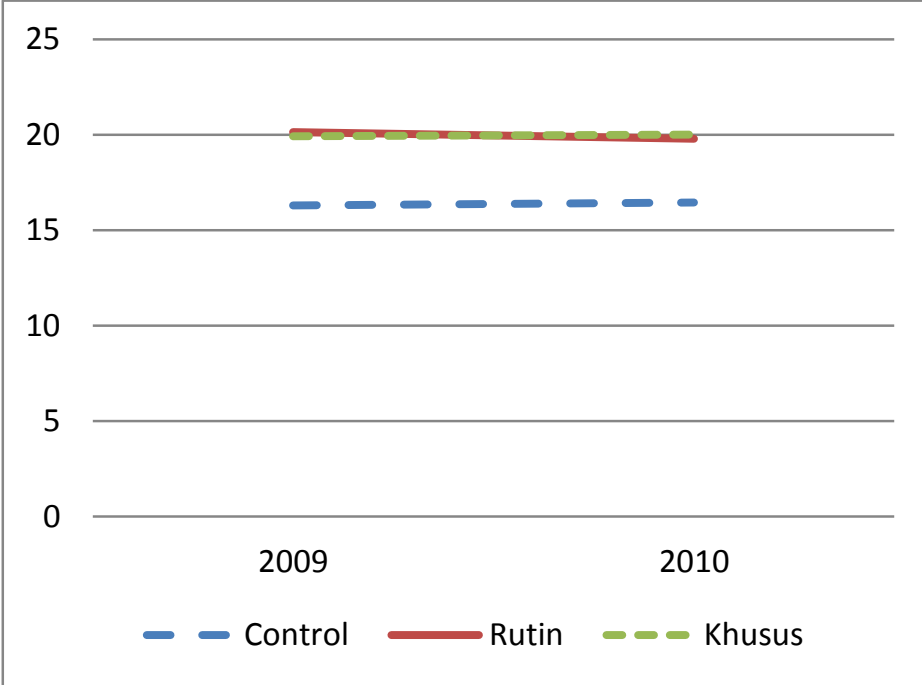

Sumber : Hasil Pengolahan Data.

Pengujian common trend dilakukan untuk PPh terutang dalam nilai logaritma yang hasilnya dapat dilihat dalam Gambar 1 dan Gambar 2. Dari kedua gambar tersebut dapat kita lihat bahwa PPh terutang dalam nilai logaritma untuk kelompok control dan kelompok treatment hampir memiliki tren yang sama sehingga tren kelompok control dan kelompok treatment secara keseluruhan untuk periode tahun 2009 ke tahun 2010 memiliki grafik yang terlihat cukup paralel. Jika kemudian kelompok treatment dibagi menjadi kelompok pemeriksaan rutin dan kelompok pemeriksaan khusus, terlihat bahwa kelompok pemeriksaan khusus dan kelompok pemeriksaan rutin 
tetap menunjukkan grafik saling silang namun pada akhirnya membentuk satu garis yang hampir lurus. Hal ini mungkin terjadi karena PPh terutang dalam nilai logaritma memiliki nilai variasi yang lebih rendah apabila dibandingkan dengan PPh terutang dalam nilai rupiah.

\section{Uji asumsi klasik.}

Pada dasarnya uji asumsi klasik sangat jarang dilakukan dalam penggunaan pendekatan DID. Namun Angrist dan Pischke (2008) serta Bertrand, Duflo, dan Mullainathan (2003) menjelaskan bahwa jika dalam penggunaan DID mengabaikan kehadiran masalah autokorelasi dan heteroskedastisitas maka akan didapatkan nilai $t$ yang cenderung lebih tinggi yang kemudian akan menyebabkan $p$-value yang lebih rendah sehingga akan cenderung menolak hipotesis null dari DID dan akan menyebabkan penerimaan yang berlebihan terhadap hipotesis alternatif, yaitu terdapat pengaruh signifikan dari pelaksanaan suatu kebijakan meskipun mungkin dalam kenyataannya pengaruh pelaksanaan kebijakan tersebut tidak cukup signifikan. Oleh karena itu uji asumsi klasik khususnya terkait dengan uji heteroskedastisitas dan autokorelasi menjadi cukup penting untuk dilaksanakan sehingga kedua permasalahan tersebut dapat dideteksi dan dapat ditemukan solusinya sehingga nilai $t$ yang didapatkan dari hasil regresi DID nantinya tidak lebih tinggi dari seharusnya.

Terkait dengan uji normalitas yang menurut pandangan clasical statistics merupakan prasyarat agar hasil regresi dapat digeneralisasi ke populasi, tidak dilakukan dalam penelitian ini. Hal ini dijelaskan oleh Park (2009) bahwa berdasarkan Central Limit Theorem, asumsi normalitas dalam dunia nyata tidak begitu problematis seperti yang selama ini dibayangkan. Berdasarkan teorema tersebut distribusi dari rata-rata sampel penelitian akan mendekati distribusi normal ketika ukuran dari sampel cukup banyak. Dalam prakteknya, jika sampel telah lebih dari 30 maka asumsi normalitas tidak perlu terlalu dikhawatirkan. Oleh karena itu, dengan alasan data yang digunakan dalam penelitian sudah cukup banyak dan tersebar di seluruh wilayah penelitian maka uji normalitas dapat dikesampingkan.

\section{Uji heteroskedastisitas}

Tujuan dari uji heteroskedastisitas adalah untuk memastikan asumsi homoskedastisitas terpenuhi, yang berarti bahwa residual pada setiap pengamatan memiliki varian yang sama. Model regresi (3.1) menggunakan model Pooled Least Squares (PLS) sedangkan model regresi (3.2) menggunakan model Fixed Effect (FE) sehingga dibutuhkan uji heteroskedastisitas yang berbeda untuk kedua model regresi tersebut. Untuk model regresi (3.1) akan digunakan Breusch-Pagan/Cook-Weisberg test for heteroskedasticity (estat hettest command) dan White's General heteroscedasticity test atau Cameron \& Trivedi's decomposition of IM-test (estat imtest command) sedangkan untuk model regresi (3.2) akan digunakan Modified Wald test for groupwise heteroskedasticity in fixed effect regression model (xttest3 command) dengan menggunakan aplikasi Stata. Hipotesis nolnya adalah residual pada setiap pengamatan memiliki varian yang sama (homoskedastis).

Berdasarkan hasil uji heteroskedastisitas didapatkan nilai $p$-value chi-square sebesar 0,0000. Nilai ini lebih kecil dari tingkat signifikansi $1 \%$ sehingga $\mathrm{H}_{0}$ tidak dapat diterima atau dengan kata lain terjadi heteroskedastisitas. Dengan demikian, asumsi homoskedastisitas tidak terpenuhi sehingga perlu dilakukan perlakuan khusus. Meskipun terdapat perbedaan model yang digunakan dalam model regresi (1) dan model regresi (2), solusi untuk kedua permasalahan tersebut untuk permasalahan heteroskedastisitas adalah sama yaitu dengan menggunakan option robust atau option bootstrap dalam aplikasi Stata.

\section{Uji multikolinearitas}

Tujuan dari uji multikolinearitas adalah untuk mengetahui adanya hubungan linier antar variabel independen. Pada penelitian ini akan dilakukan uji multikolinearitas dengan melihat nilai koefisien korelasi antar variabel independen. Dasar penetapan adanya unsur multikolinearitas mengacu pada pendapat Gujarati (2008: 337-338) bahwa korelasi antar variabel independen terbilang tidak begitu kuat jika masih jauh di bawah rule of thumb $80 \%$.

Berdasarkan hasil uji multikolinearitas, dapat disimpulkan bahwa secara umum tidak ada gejala multikolinearitas yang serius. Nilai dari koefisien korelasi berada pada kisaran antara $4,11 \%$ sampai dengan 24,35\% untuk model regresi (1) dan berada pada kisaran antara $-1,83 \%$ sampai dengan $22,11 \%$ untuk model regresi (2).

\section{Uji autokorelasi}

Tujuan dari uji autokorelasi adalah untuk mengetahui adanya autokorelasi atau sebuah kondisi dimana terjadi korelasi antara anggota-anggota dalam penelitian yang berurutan dalam waktu (dalam hal data time-series) maupun dalam ruang (dalam hal data cross-section). Dalam penelitian ini akan digunakan the runs test atau juga dikenal dengan Geary test untuk uji autokorelasi pada kedua model regresi dengan menggunakan command runtest pada aplikasi Stata. Hipotesis nolnya adalah tidak terjadi autokorelasi.

Berdasarkan hasil uji autokorelasi didapatkan nilai $p$-value $z$ sebesar 0,0000. Nilai ini lebih kecil dari tingkat signifikansi $1 \%$ sehingga $\mathrm{H}_{0}$ tidak dapat diterima atau dengan kata lain terjadi autokorelasi sehingga perlu dilakukan perlakuan khusus. Karena sebelumnya telah terdeteksi masalah heteroskedastisitas dalam kedua model regresi maka diperlukan solusi untuk mengatasi masalah heteroskedastisitas sekaligus masalah autokorelasi. Untuk model regresi (1) akan digunakan option hc3 atau option bootstrap dalam aplikasi Stata. Sedangkan untuk model regresi (2) akan digunakan option cluster/robust atau option bootstrap dalam aplikasi Stata. 


\subsection{Hasil Pengujian Data}

\section{Uji asumsi common trend}

Model regresi (1) menggunakan model regresi Pooled Least Squares (PLS) sedangkan model regresi (2) menggunakan model regresi Fixed Effect (FE). Berdasarkan uji asumsi klasik, terjadi kondisi heteroskedastisitas dan autokorelasi pada kedua model regresi tersebut. Untuk mengatasi kedua permasalahan tersebut dalam model regresi (1) akan menggunakan Davidson and MacKinnon robust standard errors for heteroskedasticity dengan menggunakan option hc3 pada aplikasi Stata sehingga syntax yang digunakan menjadi regress depvar indvar, vce(hc3).

Untuk model regresi (2), kedua permasalahan tersebut akan diatasi dengan menggunakan robust standard errors adjusted clusters in id dengan menggunakan option robust pada aplikasi Stata sehingga syntax yang digunakan menjadi xtreg depvar indvar, fe vce(robust). Option bootstrap seperti yang telas dijelaskan sebelumnya pada bagian uji asumsi klasik tidak jadi digunakan karena terdapat inkonsistensi dalam standard errors yang dihasilkan dari regresi yang dijalankan.

\section{Hasil Regresi Model 1}

Ringkasan hasil regresi dari Stata untuk model regresi (1) dan (2) serta penggunaan option bootstrap untuk kedua model regresi tersebut akan disajikan pada Tabel 2 Ringkasan Hasil Regresi Model (1) di bawah ini.

Tabel 2 Ringkasan Hasil Regresi Model (1) nilai [ ] merupakan standard errors

\begin{tabular}{|l|c|c|c|c|}
\hline \multicolumn{1}{|c|}{ Variabel } & KPP Pratama & KPP Madya & $\begin{array}{c}\text { KPP WP Besar } \\
\text { \& Khusus }\end{array}$ & Keseluruhan \\
\hline Grup $\left(\beta_{2}\right)$ & 1,692 & 1,428 & 1,349 & 3,590 \\
& {$[0,1481]$} & {$[0,0902]$} & {$[0,1745]$} & {$[0,0929]$} \\
\hline Waktu $\left(\beta_{1}\right)$ & 0,105 & 0,219 & 0,158 & 0,130 \\
& {$[0,0167]$} & {$[0,0339]$} & {$[0,1295]$} & {$[0,0207]$} \\
\hline Interaksi/ DID & $-0,125$ & $-0,033$ & $-0,056$ & $-0,027$ \\
$(\alpha)$ & & & & \\
& {$[0,2167]$} & {$[0,1248]$} & {$[0,2456]$} & {$[0,1327]$} \\
\hline Konstanta $\left(\beta_{0}\right)$ & 15,394 & 19,340 & 20,650 & 16,385 \\
& {$[0,0114]$} & {$[0,0230]$} & {$[0,0911]$} & {$[0,0143]$} \\
\hline $\mathrm{R}^{2}$ & 0,01 & 0,03 & 0,04 & 0,06 \\
\hline Observasi & 48.716 & 14.292 & 2.468 & 65.476 \\
\hline
\end{tabular}

Sumber: diolah dari hasil regresi Stata

Dari hasil regresi dalam Tabel 2 Ringkasan Hasil Regresi Model (1), yang menjadi perhatian adalah koefisien dari interaksi antara variabel dummy grup dengan variabel dummy waktu. Nilai koefisien yang disimbolkan dalam $\alpha$ tersebut merupakan nilai difference-in-differences (DID) setelah dilaksanakan pemeriksaan pajak dari kelompok treatment atau kelompok Wajib Pajak yang mengalami pemeriksaan pajak baik pemeriksaan rutin maupun pemeriksaan khusus dengan kelompok control atau kelompok Wajib Pajak yang tidak mengalami pemeriksaan pajak.

Nilai DID $(\alpha)$ dapat diinterprestasikan sebagai perbedaan rata-rata nilai logaritma natural PPh terutang antara kelompok treatment dengan kelompok control setelah dilaksanakan pemeriksaan pajak. Halvorsen dan Palmquist (dalam Gujarati, 2008:298) menawarkan cara interpretasi yang lebih mudah. Dengan menggunakan rumus $100 \times$ (e $\mathrm{e}^{\text {rata-rata nilai }}$ logaritma -1), hasil perhitungan dari rumus tersebut merupakan nilai percentage point perbedaan rata-rata variabel dependen antara kelompok treatment dengan kelompok control, yang dalam penelitian ini adalah PPh terutang.

Berdasarkan hal tersebut, koefisien $\alpha$ untuk Wajib Pajak pada KPP Pratama, KPP Madya, dan KPP Wajib Pajak Besar dan KPP Khusus berturut-turut adalah sebesar $-0,125,-0,033$, dan $-0,056$ atau sebesar $-11,75$ percentage point, $-3,25$ percentage point, dan $-5,45$ percentage point. Sedangkan Nilai $\alpha$ untuk keseluruhan Wajib Pajak adalah -0,027 atau -2,66 percentage point. Kemudian dilakukan uji signifikansi parameter individual (uji-t) untuk menguji hipotesis $\mathrm{H}_{0}$, apakah setelah pemeriksaan pajak, terdapat perbedaan yang signifikan dari tingkat kepatuhan Wajib Pajak Badan di Indonesia yang direpresentasikan dalam nilai rata-rata pelaporan PPh terutang dari kelompok yang mengalami pemeriksaan pajak (kelompok treatment) dan kelompok yang tidak mengalami pemeriksaan pajak (kelompok control).

Perbedaan nilai rata-rata pelaporan PPh terutang setelah dilaksanakan pemeriksaan pajak antara kelompok treatment dan kelompok control dapat dilihat dari nilai koefisien $\alpha$ dari model regresi (1). Penentuan apakah perbedaan tersebut signifikan atau tidak dilakukan dengan melihat nilai $p$-value hasil regresi dengan Stata. Hasil uji-t untuk masing-masing koefisien disajikan dalam Tabel 3 Ringkasan Koefisien $\alpha$ dan P-Value Hasil Regresi Model 1.

Tabel 3 Ringkasan Koefisien $\alpha$ dan P-Value Hasil Regresi Model 1

\begin{tabular}{|l|c|c|c|c|}
\hline \multicolumn{1}{|c|}{ Uji-t } & Pratama & Madya & $\begin{array}{c}\text { WP Besar } \\
\text { dan Khusus }\end{array}$ & Keseluruhan \\
\hline Nilai Koefisien & $-0,125$ & $-0,033$ & $-0,056$ & $-0,027$ \\
\hline T-Statistik & $-0,58$ & $-0,27$ & $-0,23$ & $-0,2$ \\
\hline P-Value & 0,565 & 0,789 & 0,82 & 0,838 \\
\hline Interpretasi & $\begin{array}{c}\text { Tidak } \\
\text { signifikan }\end{array}$ & $\begin{array}{c}\text { Tidak } \\
\text { signifikan }\end{array}$ & $\begin{array}{c}\text { Tidak } \\
\text { signifikan }\end{array}$ & Tidak signifikan \\
\hline
\end{tabular}

Sumber: Hasil Pengolahan Data dengan Stata.

Koefisien $\alpha$ dapat diinterpretasikan sebagai perbedaan nilai rata-rata pelaporan PPh terutang antara kelompok treatment dan kelompok control setelah dilaksanakan pemeriksaan pajak baik pemeriksaan rutin maupun pemeriksaan khusus. Dari Tabel 5 Ringkasan Koefisien $\alpha$ dan P-Value Hasil Regresi Model 1 dapat dilihat bahwa nilai $p$-value hasil regresi yang dihasilkan dapat disimpulkan bahwa $\mathrm{H}_{0}$ diterima karena perbedaan nilai rata-rata pelaporan PPh terutang antara kelompok treatment dan kelompok control setelah dilaksanakan pemeriksaan pajak baik pemeriksaan rutin maupun pemeriksaan khusus tidak signifikan.

Dari hasil estimasi dan pengujian hipotesis Model 1 dapat disimpulkan bahwa setelah dilakukan pemeriksaan pajak, tidak terdapat perbedaan tingkat kepatuhan antara Wajib Pajak Badan di Indonesia yang mengalami pemeriksaan pajak dengan Wajib Pajak Badan yang tidak mengalami pemeriksaan pajak. 
Hasil Regresi Model 2 (Pemeriksaan Rutin vs Pemeriksaan Khusus)

Berlanjut ke pengujian ke model penelitian berikutnya, Model 2 dimana dalam model ini, jenis pemeriksaan dipisahkan menjadi Pemeriksaan Khusus dan Pemeriksaan Rutin. Hal ini dimaksudkan untuk men-capture adanya perbedaan karakteristik antara dua jenis pemeriksaan tersebut.

Nilai koefisien dari interaksi antara variabel dummy pemeriksaan rutin dengan variabel dummy waktu yang disimbolkan dalam $\alpha_{1}$ tersebut merupakan nilai difference-in-differences (DID) setelah dilaksanakan pemeriksaan pajak dari kelompok Wajib Pajak yang mengalami pemeriksaan rutin dengan kelompok control atau kelompok Wajib Pajak yang tidak mengalami pemeriksaan pajak sedangkan Nilai koefisien dari interaksi antara variabel dummy pemeriksaan khusus dengan variabel dummy waktu yang disimbolkan dalam $\alpha_{2}$ tersebut merupakan nilai difference-in-differences (DID) dari kelompok Wajib Pajak yang mengalami pemeriksaan khusus dengan kelompok control atau kelompok Wajib Pajak yang tidak mengalami pemeriksaan pajak. Tabel 4 menunjukkan Ringkasan Hasil Regresi Model (2).

Tabel 4 Ringkasan Hasil Regresi Model (2)

\begin{tabular}{|l|c|c|c|c|}
\hline \multicolumn{1}{|c|}{ Variabel } & $\begin{array}{c}\text { KPP } \\
\text { Pratama }\end{array}$ & $\begin{array}{c}\text { KPP } \\
\text { Madya }\end{array}$ & $\begin{array}{c}\text { KPP WP Besar \& } \\
\text { Khusus }\end{array}$ & Keseluruhan \\
\hline Waktu $\left(\beta_{1}\right)$ & $\begin{array}{c}0,105 \\
{[0.0089]}\end{array}$ & $\begin{array}{c}0,219 \\
{[0,0142]}\end{array}$ & $\begin{array}{c}0,158 \\
{[0,0426]}\end{array}$ & $\begin{array}{c}0,131 \\
{[0,0075]}\end{array}$ \\
\hline $\begin{array}{l}\text { Interaksi/ DID } \\
\text { Rutin }\left(\alpha_{1}\right)\end{array}$ & $-0,151$ & $-0,073$ & $-0,061$ & $-0,053$ \\
& {$[0.1008]$} & {$[0,0850]$} & {$[0,0921]$} & {$[0,0521]$} \\
\hline Interaksi/ DID & $-0,038$ & 0,099 & 0,021 & 0,085 \\
Khusus $\left(\alpha_{2}\right)$ & {$[0.1501]$} & {$[0,0856]$} & {$[0,2522]$} & {$[0,0761]$} \\
\hline Konstanta $\left(\beta_{0}\right)$ & 15,416 & 19,436 & 20,943 & 16,502 \\
& {$[0,0044]$} & {$[0,0070]$} & {$[0,0187]$} & {$[0,0037]$} \\
\hline $\mathrm{R}^{2}$ & 0,01 & 0,04 & 0,01 & 0,03 \\
\hline Observasi & 48.716 & 14.292 & 2.468 & 65.476 \\
\hline
\end{tabular}

nilai [ ] merupakan standard errors

Sumber: diolah dari hasil regresi Stata 12

Uji signifikansi parameter individual (uji-t) kemudian dilakukan untuk menguji hipotesis $\mathrm{H}_{0}$ apakah setelah pemeriksaan pajak, terdapat perbedaan yang signifikan dari tingkat kepatuhan Wajib Pajak Badan di Indonesia yang direpresentasikan dalam nilai rata-rata pelaporan PPh terutang dari kelompok yang mengalami pemeriksaan pajak (kelompok treatment) dan kelompok yang tidak mengalami pemeriksaan pajak (kelompok control). Perbedaan nilai rata-rata pelaporan PPh terutang setelah dilaksanakan pemeriksaan pajak antara kelompok treatment dan kelompok control dapat dilihat dari koefisien $\alpha_{1}$ dan $\alpha_{2}$ dari model regresi (2). Penentuan apakah perbedaan tersebut signifikan atau tidak dilakukan dengan melihat nilai $p$-value hasil regresi dengan Stata. Hasil uji-t untuk masing-masing koefisien disajikan dalam Tabel 5 Ringkasan Koefisien $\alpha$ dan P-Value Hasil Regresi Model 2.

Tabel 5 Ringkasan Koefisien $\alpha_{1}$ dan P-Value Hasil Regresi Model 2

\begin{tabular}{|l|c|c|c|c|}
\hline \multicolumn{1}{|c|}{ Jenis KPP } & Pratama & Madya & $\begin{array}{c}\text { WP Besar } \\
\text { dan Khusus }\end{array}$ & Keseluruhan \\
\hline Nilai Koefisien & $-0,151$ & $-0,073$ & $-0,061$ & $-0,053$ \\
\hline T-Statistik & $-1,5$ & $-0,86$ & $-0,66$ & $-1,02$ \\
\hline
\end{tabular}

\begin{tabular}{|l|c|c|c|c|}
\hline P-Value & 0,135 & 0,388 & 0,51 & 0,309 \\
\hline Interpretasi & $\begin{array}{c}\text { Tidak } \\
\text { signifikan }\end{array}$ & $\begin{array}{c}\text { Tidak } \\
\text { signifikan }\end{array}$ & $\begin{array}{c}\text { Tidak } \\
\text { signifikan }\end{array}$ & Tidak signifikan \\
\hline
\end{tabular}

Sumber: Hasil Pengolahan Data dengan Stata

Koefisien $\alpha_{1}$ dapat diinterpretasikan sebagai perbedaan nilai rata-rata pelaporan PPh terutang antara kelompok treatment dan kelompok control setelah dilaksanakan pemeriksaan rutin. Dari Tabel 5 dapat dilihat bahwa nilai $p$-value hasil regresi yang dihasilkan dapat disimpulkan bahwa $\mathrm{H}_{0}$ diterima karena perbedaan nilai rata-rata pelaporan PPh terutang antara kelompok treatment dan kelompok control setelah dilaksanakan pemeriksaan rutin tidak signifikan.

Tabel 6 di bawah ini menunjukkan hasil pengujian hipotesis untuk koefisien $\alpha_{2}$ yaitu sebagai perbedaan nilai rata-rata pelaporan PPh terutang antara kelompok treatment dan kelompok control setelah dilaksanakan pemeriksaan khusus.

Tabel 6 Ringkasan Koefisien $\alpha_{2}$ dan P-Value Hasil Regresi Model 2

\begin{tabular}{|l|c|c|c|c|}
\hline \multicolumn{1}{|c|}{ Jenis KPP } & Pratama & Madya & $\begin{array}{c}\text { WP Besar } \\
\text { dan Khusus }\end{array}$ & Keseluruhan \\
\hline Nilai Koefisien & $-0,038$ & 0,099 & 0,021 & 0,085 \\
\hline T-Statistik & $-0,25$ & 1,15 & 0,09 & 1,11 \\
\hline P-Value & 0,803 & 0,248 & 0,932 & 0,265 \\
\hline Interpretasi & $\begin{array}{c}\text { Tidak } \\
\text { signifikan }\end{array}$ & $\begin{array}{c}\text { Tidak } \\
\text { signifikan }\end{array}$ & $\begin{array}{c}\text { Tidak } \\
\text { signifikan }\end{array}$ & Tidak signifikan \\
\hline
\end{tabular}

Sumber: Hasil Pengolahan Data dengan Stata

Dari Tabel 6 Ringkasan Koefisien $\alpha_{2}$ dan P-Value Hasil Regresi Model 2 dapat dilihat bahwa nilai $p$-value hasil regresi yang dihasilkan dapat disimpulkan bahwa $\mathrm{H}_{0}$ diterima karena perbedaan nilai rata-rata pelaporan PPh terutang antara kelompok treatment dan kelompok control setelah dilaksanakan pemeriksaan khusus tidak signifikan.

Dari hasil estimasi dan pengujian hipotesis Model 2 dapat disimpulkan bahwa setelah dilakukan pemeriksaan pajak, baik Pemeriksaan Khusus maupun Pemeriksaan Rutin, tidak terdapat perbedaan tingkat kepatuhan antara Wajib Pajak Badan di Indonesia yang mengalami pemeriksaan pajak dengan Wajib Pajak Badan yang tidak mengalami pemeriksaan pajak. Meskipun menghasilkan nilai yang tidak signifikan secara statistic, namun terdapat perbedaan nilai ratarata pelaporan PPh terutang antara kelompok treatment dan kelompok control. Seluruh Pemeriksaan Rutin $\left(\alpha_{1}\right)$ menunjukkan nilai negative, meskipun secara statistic tetap menunjukkan kecenderungan ke arah nol, Sedangkan hasil estimasi untuk Pemeriksaan Khusus $\left(\alpha_{2}\right)$ menunjukkan kecenderungan bernilai positif, kecuali untuk KPP Pratama.

\subsection{Pembahasan \\ Uji asumsi common trend}

Dari hasil estimasi dan pengujian hipotesis Model 1 dan Model 2 dapat disimpulkan bahwa setelah dilakukan pemeriksaan, baik Pemeriksaan Khusus maupun Pemeriksaan Rutin, tidak terdapat perbedaan tingkat kepatuhan antara Wajib Pajak Badan antara Wajib Pajak yang diperiksa maupun Wajib Pajak yang tidak mengalami pemeriksaan pajak. 
Namun yang menarik adalah tanda positif atau negatif yang ditunjukkan oleh koefisien $\alpha_{1}$ dan $\alpha_{2}$. Koefisien untuk Pemeriksaan Rutin $\left(\alpha_{1}\right)$ menunjukkan nilai negatif pada seluruh pengujian. Hal ini menunjukkan bahwa pemeriksaan rutin tidak memiliki impact terhadap kepatuhan Wajib Pajak. Hal ini bisa dimengerti karena Pemeriksaan Rutin ini merupakan pemeriksaan atas pengajuan restitusi. Wajib Pajak mengalami kelebihan bayar PPh karena terdapat kredit pajak yang lebih besar dibandingkan kewajiban pajaknya sehingga mengajukan pengembalian kelebihan PPh tersebut. Hal ini berarti Wajib Pajak telah siap diperiksa karena dalam Pasal 17B UU Ketentuan Umum dan Tata Cara Perpajakan, dalam hal Wajib Pajak mengajukan restitusi maka dirjen pajak akan melakukan pemeriksaan.

Sedangkan koefisien untuk Pemeriksaan Khusus $\left(\alpha_{2}\right)$ menunjukkan kecenderungan bernilai positif, kecuali untuk KPP Pratama. Hal ini mengindikasikan adanya kemungkinan pengaruh pemeriksaan khusus terhadap kepatuhan Wajib Pajak Badan, meskipun nilainya sangat kecil. Dalam populasi data panel penelitian ini, jumlah Pemeriksaan Khusus hanya mencapai $4.16 \%$, bandingkan populasi Pemeriksaan Rutin yang mencapai $95.84 \%$ dari total pemeriksaan pajak secara keseluruhan. Hal tersebut menjadikan adanya kemungkinan pengaruh yang ditimbulkan oleh Pemeriksaan Khusus sangat kecil untuk diamati secara statistic. Ditambah lagi dengan data bahwa Audit Coverage Ratio/ACR yang masih cukup rendah yaitu berada di bawah $2 \%$ maka, hal inilah yang kemungkinan menyebabkan pengaruh Pemeriksaan Khusus terhadap kepatuhan hamper tidak ada atau cenderung mendekati nol.

Hasil penelitian di negara lainnya menunjukkan hal yang bervariasi. Penelitian Niu (2010) serta Gemmell dan Ratto (2012) memberikan kesimpulan bahwa setelah dilaksanakan pemeriksaan pajak, kepatuhan Wajib Pajak mengalami peningkatan sedangkan penelitian Bergman dan Nevarez (2006) serta DeBacker et al. (2013) memberikan kesimpulan sebaliknya yaitu kepatuhan Wajib Pajak setelah pemeriksaan pajak justru menunjukkan penurunan. Dengan melihat perbandingan kedua penelitian tersebut, hasil regresi dalam penelitian ini, dimana hasil regresi menunjukkan tidak-adanya pengaruh kepatuhan setelah pemeriksaan, bukanlah hal yang mengagetkan. Bahkan, temuan dalam pemeriksaan ini berada dalam rentang temuan penelitian-penelitian yang lainnya.

Tidak adanya perbedaan tingkat kepatuhan Wajib Pajak setelah dilaksanakan pemeriksaan pajak ini dapat dijelaskan karena beberapa hal, antara lain kecilnya cakupan pemeriksaan pajak (Audit Coverage Ratio/ACR), adanya fenomena bomb crater effect dan hasil type-updating risiko pemeriksaan.

Cakupan pemeriksaan pajak (Audit Coverage Ratio/ACR), di Indonesia yang masih cukup rendah yaitu berada di bawah $2 \%$ dari keseluruhan Wajib Pajak yang terdaftar. Hal tersebut diperparah dengan komposisi Pemeriksaan Rutin yang jauh lebih dominan dibandingkan dengan Pemeriksaan Khusus.
Berdasarkan buku Analisis Deskriptif Pemeriksaan 2012, diketahui bahwa persentase Pemeriksaan Rutin terhadap Pemeriksaan Khusus mencapai 86\%:14\%. Dengan kecilnya proporsi Pemeriksaan Khusus, sulit untuk berharap bahwa pemeriksaan ini memiliki pengaruh yang signifikan terhadap kepatuhan.

Di lain pihak, Pemeriksaan Rutin sulit diharapkan untuk dapat meng-upgrade kualitas pemeriksaan atau peningkatan kepatuhan Wajib Pajak. Mengingat pada dasarnya pemeriksaan ini timbul akibat permintaan Wajib Pajak itu sendiri. Pemeriksaan Rutin sebenarnya adalah pemeriksaan yang dilakukan terhadap Wajib Pajak yang memang telah siap diperiksa. Sehingga adalah hal yang logis apabila tidak terjadi peningkatan kepatuhan yang setelah Pemeriksaan Rutin.

Ketiadaan respon kepatuhan Wajib Pajak akibat pemeriksaan bisa juga terjadi karena adanya bomb crater effect. Dalam konteks pemeriksaan pajak, fenomena ini terjadi ketika setelah dilaksanakan pemeriksaan, Wajib Pajak tidak bereaksi atau bahkan menurunkan kepatuhannya karena beranggapan bahwa kemungkinan untuk diperiksa kembali pada masa yang akan datang menjadi lebih kecil. Wajib Pajak merasa aman karena telah mendapatkan "jatah" pemeriksaan, sehingga punya kecenderungan untuk mengabaikan atau bahkan menurunkan kepatuhannya. Dari hasil penelitian ini, tampak terjadi bomb crater effect pada Wajib Pajak exist, dan bila melihat kecenderungannya, maka secara khusus pemeriksaan rutin sepertinya lebih memungkinkan menghasilkan adanya efek ini karena sign koefisiennya yang menunjukkan arah negatif

Minimnya pengaruh kepatuhan Wajib Pajak setelah dilakukannya pemeriksaan bisa jadi merupakan hasil type-updating risiko pemeriksaan. DeBacker et al. (2013) menjelaskan bahwa sebelum mengalami pemeriksaan pajak, Wajib Pajak menentukan tingkat dan tipe risiko pemeriksaan dalam rangka menetapkan tinggi-rendahnya tingkat kepatuhan Wajib Pajak. Tipe risiko pemeriksaan ini sangat variatif, dari rendah hingga tinggi sesuai dengan yang diyakini oleh Wajib Pajak. Lebih lanjut, Alm (2013) menambahkan bahwa Wajib Pajak cenderung menilai risiko pemeriksaan pajak secara berlebihan (overweight), yaitu lebih tinggi dari risiko pemeriksaan pajak yang sebenarnya. Setelah pemeriksaan, DeBacker et al (2013) menyebutkan bahwa Wajib Pajak akan melakukan pembaharuan tipe risiko (type-updating risk) pemeriksaan pajak sesuai dengan pengalaman pemeriksaan pajak yang dialaminya. Jika ternyata setelah pemeriksaan, Wajib Pajak meyakini risiko pemeriksaan yang dihadapi lebih tinggi, hal ini akan mendorong kepatuhan menjadi lebih tinggi.

Sebaliknya, jika ternyata setelah pemeriksaan pajak, Wajib Pajak meyakini risiko pemeriksaan yang dihadapi lebih rendah karena otoritas pajak gagal mendeteksi tindakan ketidakpatuhannya, maka Wajib Pajak akan melakukan type-updating yang lebih rendah. Pada akhirnya, hal ini akan mendorong kepatuhan menjadi lebih rendah dari kepatuhan sebelum pemeriksaan pajak. 
Dalam penelitian ini, type-updating risk yang ditetapkan oleh Wajib Pajak setelah pemeriksaan kemungkinan tidak beranjak dari level yang sebelumnya. Hal ini kemungkinan terjadi karena perilaku ketidakpatuhan Wajib Pajak tidak ditemukan dalam pemeriksaan sehingga Wajib Pajak tidak menjadi lebih patuh setelah pemeriksaan. Hal ini senada dengan DeBacker et al (2013) yang menyebutkan bahwa Wajib Pajak akan melakukan pembaharuan tipe risiko (type-updating risk) pemeriksaan pajak sesuai dengan pengalaman pemeriksaan pajak yang dialaminya. Jika dalam pemeriksaan pajak otoritas pajak berhasil mengidentifikasi perilaku noncompliance, maka Wajib Pajak akan melakukan type-updating risk dengan menjadi lebih compliance dibandingkan sebelumnya. Namun sebaiknya bila jumlah pemeriksaan terlalu kecil dan tidak berhasil menemukan perilaku noncompliance maka Wajib Pajak terdorong untuk tetap meneruskan perilaku noncompliance atau bhkan menurunkan level kepatuhannya.

\section{KESIMPULAN}

Berdasarkan hasil pengujian dan pembahasan, diperoleh simpulan sebagai berikut:

1. Tidak terdapat perbedaan tingkat kepatuhan yang signifikan antara Wajib Pajak Badan yang diperiksa maupun Wajib Pajak Badan yang tidak mengalami pemeriksaan pajak.

2. Tidak adanya perbedaan tingkat kepatuhan Wajib Pajak setelah dilaksanakan pemeriksaan pajak ini dapat kemungkinan disebabkan oleh beberapa faktor, antara lain kecilnya cakupan pemeriksaan pajak (Audit Coverage Ratio/ACR), adanya fenomena bomb crater effect dan hasil typeupdating risiko pemeriksaan.

3. Cakupan pemeriksaan pajak (Audit Coverage Ratio/ACR) masih cukup rendah, yaitu berada di bawah $2 \%$, dan proporsi Pemeriksaan Rutin yang lebih dominan dibandingkan dengan Pemeriksaan Khusus kemungkinan menjadi faktor utama penyebab tidak adanya pengaruh pemeriksaan terhadap kepatuhan Wajib Pajak.

4. Ketiadaan respon kepatuhan Wajib Pajak akibat pemeriksaan bisa juga terjadi karena adanya bomb crater effect. Wajib Pajak merasa aman karena telah mendapatkan giliran pemeriksaan, sehingga punya kecenderungan untuk mengabaikan atau bahkan menurunkan kepatuhannya.

5. Minimnya pengaruh kepatuhan Wajib Pajak setelah dilakukannya pemeriksaan bisa juga berasal dari hasil type-updating risiko pemeriksaan, yang tidak lebih tinggi dibandingkan dengan risiko pemeriksaan sebelumnya. Hasil type-updating risk yang ditetapkan oleh Wajib Pajak setelah pemeriksaan kemungkinan tidak beranjak dari level yang sebelumnya karena inefektifitas dalam pemeriksaan, seperti kegagalan pemeriksa dalam mengidentifikasi perilaku ketidakpatuhan.

\section{DAFTAR PUSTAKA}

Advani, Arun., William Elming dan Jonathan Shaw. (2015). How Long Lasting are the Effects of Audits. Tax Administration Research Centre 011-15, Januari 2015.

Allingham, Michael, dan Agnar Sandmo. (1972). Income Tax Evasion: Theoretical Analysis. Journal of Public Economics. 1(3-4): 323-338.

Alm, James. (2012). Measuring, Explaining, and Controlling Tax Evasion: Lessons from Theory, Experiments and Filed Studies. Tulane Economics Working Paper Series: 1213.

Alm, James dan Michael McKee. (2006). Audit Certainty, Audit Productivity, and Taxpayer Compliance. Andrew Young School of Policy Studies Research Paper. No. 06-43.

Alm, James. dan Kim M. Bloomquist. (2013). On External Validity of Laboratory Policy Experiment. Department of Economics, Tulane University. Maret.

Alm, James, Michael McKee, dan William Beck. (1990). Amazing Grace: Tax Amnesties and Compliance. National Tax Journal. Vol.43(1): 23-37.

Alm, James, Betty Jackson, dan Michael McKee. (1992a). Estimating the Determinants of Taxpayer Compliance with Experimental Data. National Tax Journal. Vol.45(1): 107-144.

Alm, James, Betty Jackson, dan Michael McKee. (1992b). Institutional Uncertainty and Taxpayer Compliance. The American Economic Review. Vol. 82(4): 1018-1026.

Almunia, Miguel dan David Lopez-Rodriguez. (2014). Heterogeneous Responses to Effective Tax Enforcement: Evidence from Spanish Firms. University of Warwick Banco de España.

Analisis Deskriptif Pemeriksaan. (2013). Direktorat Pemeriksaan dan Penagihan. Direktorat Jenderal Pajak.

Andreoni, James, Brian Errard, dan Jonathan Feinstein. (1998). Tax Compliance. Journal of Economic Literature. Vol.36, No.2, Jun., pp. 818-860. American Economic Association.

Angrist, Joshua D. dan Jorn-Steffen Pischke. (2008). Mostly Harmless Econometrics: An Empiricist's Companion. MIT Press.

Arens, Alvin A., Randal J. Elder dan Mark S. Beasley. (2012). Auditing and Assurance Services: An 
Integrated Approach. Edisi ke-14. New Jersey: Pearson Education, Inc.

Arnold, J. (2012). Improving the Tax System in Indonesia. OECD Economics Department Working Papers. No. 998. OECD Publishing.

Bergman, Marcelo dan Armando Nevarez. (2006). Do Audits Enhance Compliance? An Empirical Assessment of VAT Enforcement. National Tax Journal. Vol.LIX, No.4, December, pp. 817-832.

Bernasconi, Michele. (1998). Tax Evasion and Orders of Risk Aversion. Journal of Public Economics. Vol.67 123-134. Elsevier Science Publishers B.V. North Holland.

Bertrand, Marianne., Esther Duflo dan Sendhil Mullainathan. (2004). How Much Should We Trust Differences-In-Differences Estimates? The Quarterly Journal of Economics. MIT Press. Vol. 119(1), pages 249-275, Pebruari.

Brown, Robert E., dan Mark J. Mazur. (2003). IRS's Comprehensive Approach to Compliance Measurement. Internal Revenue Service.

Birskyte, Liucija. (2013). Effects of tax Auditing: Does The Deterrent Deter? Research Journal of Economics, Business and ICT. Volume 8, Issue 2.

Cameron, A. Colin dan Pravin K. Travedi. (2005). Microeconometrics: Methods and Applications. Cambridge University Press : New York.

DeBacker, Jason, Bradley T. Heim, Anh Tran, dan Alexander Yuskavage. (2013). The Impact of Legal Enforcement : An Analysis of Corporate Tax Aggressiveness after an Audit.

Dhami, Sanjit dan Ali al-Nowaihi. (2004). Why Do People Pay Taxes? Prospect Theory Versus Expected Utility Theory. Department of Economics, University of Leichester.

Dubin, Jefrey A. (2004). Criminal Investigation Enforcement Activities and Taxpayer Noncompliance. California Institute of Technology.

Dubin, Jefrey A. dan Louis L. Wilde. (1988). An Empirical Analysis of Federal Income Tax Auditing and Compliance. National Tax Journal, Vol. LXI, No.1, Maret: 61-74.

Dubin, Jefrey A. dan Michael J. Graetz. (1987). Are We a Nation of Tax Cheaters? New Econometric Evidence on Tax Compliance. AEA Paper and Proceedings: Economic Analysis of Taxpayers Compliance, Vol.77, No.2, May: 240-245.
Dubin, Jefrey A. (1990). The Effect of Audit Rates on the Federal Individual Income Tax 1977-1986. National Tax Journal, Vol. 43, No. 4, December: 395-409.

Erard, Brian dan Jonathan S. Feinstein. (1994). Honesty and Evasion in the Tax Compliance Game. The RAND Journal of Economics. Blackwell Publishing. Vol.25, No.1 (Spring) pp.1-19.

Feldman, Naomi E., dan Joel Slemrod. (2005). Estimating Tax Noncompliance with Evidence from Unaudited Tax Returns. Discussion Paper. No. 05-15. Monaster Center for Economic Research. Ben-Gurion University of Negev. Beer Sheva: Israel. July.

Fiorio, Carlo dan Alessandro Santoro. (2012). Taxpayer response to an increased probability of audit: some evidence from Italy. University of Milan.

Franklin, Jon. Network and Taxpayer Non-Compliance. (2009). London, HM Revenue \& Customs. September.

Gahramanov, Emin. (2009). The Theoritical Analysis of Income Tax Evasion Revisited. Economic Issues. Vol.14, Part 1.

Gemmell, Norman dan Marissa Ratto. (2012). Behavioral Responses to Taxpayer Audits : Evidence from Random Taxpayer Inquiries. National Tax Journal. Vol. 65(1), 33-58, March.

Gideon, Yaniv. (1999). Tax Compliance and Advance Tax Payments : A Prospect Theory Analysis. National Tax Journal. Vol. 52 (4). pp. 753-765.

Guala, Francesco dan Luigi Mittone. (2005). Experiment in Economics : Testing Theories vs. The Robustness of Phenomena. Centre for Philosophy of the Social Sciences, University of Exeter.

Gujarati, Damodar N.(2008). Basic Econometrics. Edisi ke-5. The McGraw-Hill Companies.

Hanlon, Michelle., Lillian Mills dan Joel Slemrod. (2005). An Empirical Examination of Corporate Tax Noncompliance. Ross School of Business Working Paper Series Working Paper No. 1025, Juni 2005.

Hashimzade, Nigar., Gareth D. Myles, Frank Page dan Matthew D. Rablen. (2014). Social networks and occupational choice: The endogenous formation of attitudes and beliefs about tax compliance. Journal of Economic Psychology 40: 134-146.

Imbens, Guido W dan Jeffrey M. Wooldridge. (2009). Recent Developments In The Econometrics Of Program Evaluation. Journal Of Economic Literature 47, no. 1: 5-86, hal: 63-64. 
Isa, Khadijah dan Jeff Pope. (2011). Corporate Tax Audits : Evidence from Malaysia. Global Review of Accounting and Finance. Vol.2(1): pp.42-56.

Kastlunger, Barbara, Erich Kirchler, Luigi Mittone, dan Julia Pitters. (2009). Sequences of Audits, Tax Compliance, and Taxpaying Strategies. Journal of Economic Psychology. Vol.30(3): 405-418.

Kirchler, Eric., Boris Maciejovsky dan Friedrich Schneider. (2001). Everyday Representations of Tax Avoidance, Tax Evasion, and Tax Flight: Do Legal Differences Matter?. University of Vienna, Juni.

Kirchler, Eric., Erik Hoelzl dan Ingrid Wahl. (2008). Enforced Versus Voluntary Tax Compliance: The "Slippery Slope" Framework. Journal of Economic Psychology 29: 210-225.

Kleven, Henrik Jacobsen., Martin B. Knudsen, Claus Thustrup Kreiner, Søren Pedersen, dan Emmanuel Saezl. (2011). Unwilling Or Unable To Cheat? Evidence From A Tax Audit Experiment In Denmark. Econometrica Vol. 79, No. 3, Mei 2011, hal: 651-692.

Laporan Tahunan. (2009) Direktorat Jenderal Pajak. Kementerian Keuangan Republik Indonesia.

Laporan Tahunan. (2010). Direktorat Jenderal Pajak. Kementerian Keuangan Republik Indonesia.

Laporan Tahunan. (2011). Direktorat Jenderal Pajak. Kementerian Keuangan Republik Indonesia.

Laporan Tahunan. (2012). Direktorat Jenderal Pajak. Kementerian Keuangan Republik Indonesia.

Lechner, Michael. (2011). The Estimation of Causal Effects by Difference-in-Difference Methods. Discussion Paper no. 2010-28. Department of Economics University of St. Gallen, Oktober.

Levine, David M., David Stephan, Mark L. Berenson, dan Timothy C. Krehbiel. (2008). Statistics for Managers Using Microsoft Excel. Edisi ke-6.

Lipatov, Vilen. (2003). Evolution of Tax Evasion. MPRA Paper. European University Institute. No.966.

Maciejovsky, Boris., Erich Kirchler, dan Herbert Schwarzenberger. (2007). Misperception of chance and loss repair: On the dynamics of tax compliance. Journal of Economic Psychology 28, hal: 678-691.

Mardiasmo. (2013). Perpajakan Edisi Revisi. Yogyakarta: Penerbit ANDI.
McKee, Michael, Caleb Siladke, dan Christian A. Vossler. (2011). Behavioral Dynamics of Tax Compliance Under An Information Services Initiative. MPRA Paper. No. 38865.

Mittone, Luigi. (2006). Dynamic Behaviours in Tax Evasion: An Experimental Approach. Department of Economics, CEEL, University of Trento.

Niu, Yongzhi. (2010). Tax Audit Impact on Voluntary Compliance. MPRA Paper. New York State Department of Taxation and Finance. No.966.

Nurmantu, Safri. (2005). Pengantar Perpajakan. Edisi Ke-3. Jakarta: Granit.

Okello, Andre. (2014). Managing Income Tax Compliance through Self-Assessment. IMF Working Paper, 14/41, Maret.

Organisation For Economic Co-Operation And Development (OECD). (2006). Strengthening Tax Audit Capabilities: General Principles and Approaches. Information Notes.

Organisation For Economic Co-Operation And Development (OECD). (2004). Compliance Risk Management: Audit Case Selection Systems. Information Notes.

Organisation For Economic Co-Operation And Development (OECD). (2004). Compliance Risk Management : Use of Random Audit Programs. Information Notes.

Park, Hun Myoung. (2009). Comparing Group Means: Ttests and One-way ANOVA Using STATA, SAS, R, and SPSS. Working Paper. The University Information Technology Services (UITS) Center for Statistical and Mathematical Computing, Indiana University.

Plumley, Alan H. (1996). The Determinants of Individual Income Tax Compliance: Estimating the Impacts of Tax Policy, Enforcement, and IRS Responsiveness. Publication 1916 (Rev. 11-96). Washington DC.

Plumley, Alan H. (2002). The Impact of the IRS on Voluntary Tax Compliance: Preliminary Empirical Results. National Tax Association 95th Annual Conference On Taxation, 14-16. November 2002

Pomeranz, Dina. (2010). No Taxation Without Information: Deterrence And Self-Enforcement In The Value Added Tax. Job Market Paper, Januari.

Rablen, Matthew D. (2012). Audit Probability versus Effectiveness: The Beckerian Approach 
Revisited. Economics and Finance Working Paper Series No. 12-04. Pebruari.

Ratto, Marisa., Richard Thomas dan David Ulph. (2013). The Indirect Effects of Auditing Taxpayers. Public Finance Review, vol. 41 no. 3: 317-333.

Reinganum, Jennifer F., dan Louis L. Wilde. (1985). Income Tax Compliance in Principal-Agent Framework. Journal of Public Economics. Elsevier Science Publishers B.V. North Holland. Vol.26 1-18.

Rumsey, Deborah. (2010). Statistics Essentials for Dummies. United States of America: Wiley Publishing.

Sandmo, Agnar. (2005). The theory of Tax Evasion: a Retrospective View. National Tax Journal vol 58, Issue 4, hal 643-63.

Sapiei, Noor Sharoja dan Jeyapalan Kassippelai. (2013). Impacts of the Self-Assessment System for Corporate Taxpayers. American Journal of Economics, 3(2): 75-81.

Sekaran, Uma. (2003). Research Methods for Business: A Skill-Building Approach. 4th Edition. John Wiley $\&$ Sons, Inc., New York.

Siregar, Syofian. (2013). Statistika Parametrik untuk Penelitian Kuantitatif: Dilengkapi dengan Perhitungan Manual dan Aplikasi SPSS versi 17. Jakarta: Bumi Aksara.

Slemrod, Joel., Marsha Blumenthal dan Charles Christian (2001).Taxpayer Response to an Increased Probability of Audit: Evidence from a Controlled Experiment in Minnesota. Journal of Public Economics 79, 455-483.

Slemrod, Joel., dan Shlomo Yitzhaki. (2003). Tax Avoidance, Evasion, and Administration. Handbook of Public Economics, Vol.3, 1425 1465. North-Holland : Elsevier Science B.V.

Stiglitz, Joseph E.. (1985). The General Theory of Tax Avoidance. National Tax Journal. Vol.XXXVIII No.3. pp. 325-337.

Sumarsan, Thomas. (2013). Perpajakan Indonesia Edisi 3 Revisi. Jakarta: PT Indeks.

Tauchen, Helen V., Ann Dryden Witte, dan Kurt J. Baron. (1989). Tax Compliance: An Investigation Using Individual TCMP Data. Working Paper No.3078. National Bureau of Economic Research. Cambridge: Massachusetts. Agustus. 